Historic, Archive Document

Do not assume content reflects current scientific knowledge, policies, or practices. 


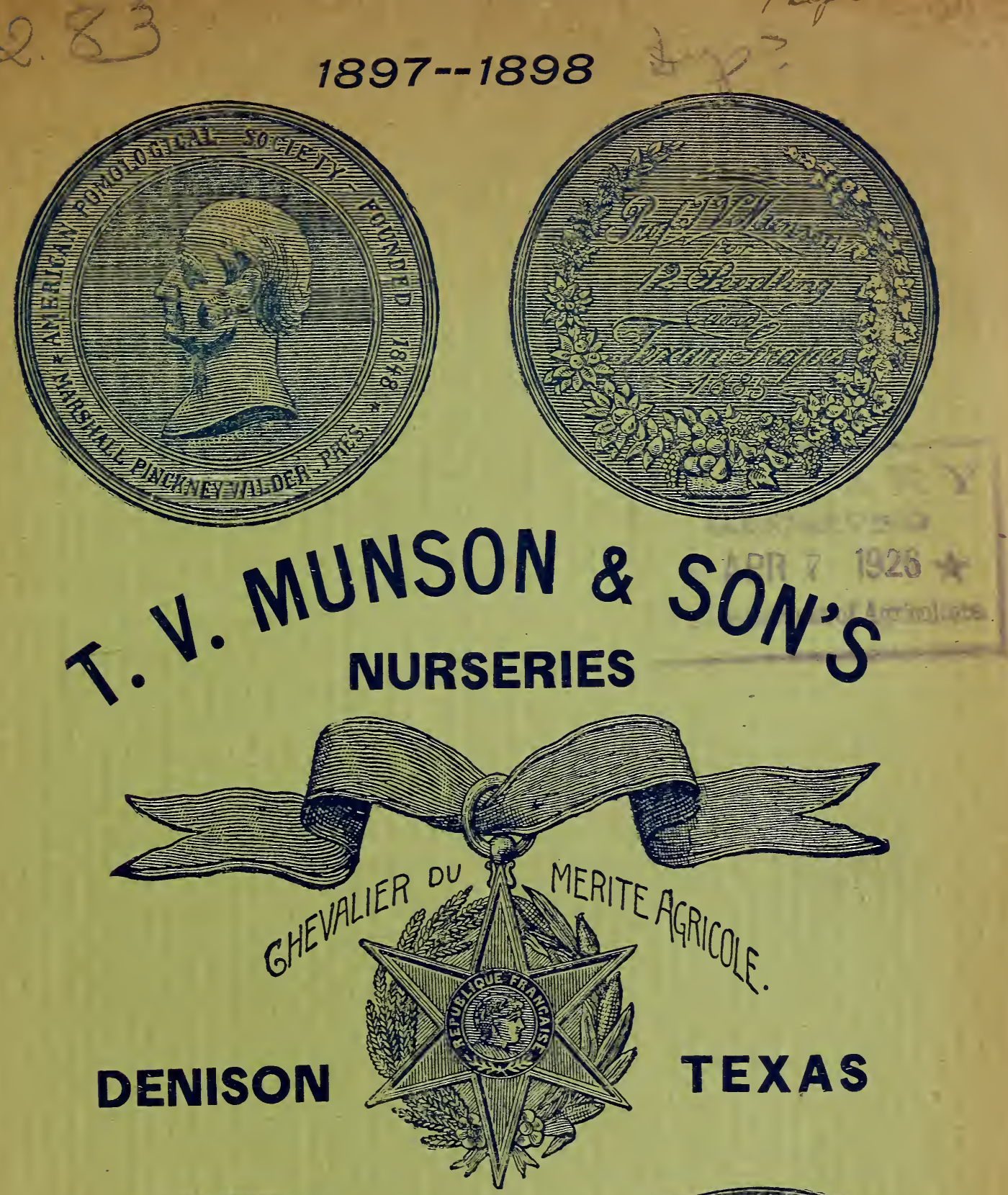

DENISON \&,
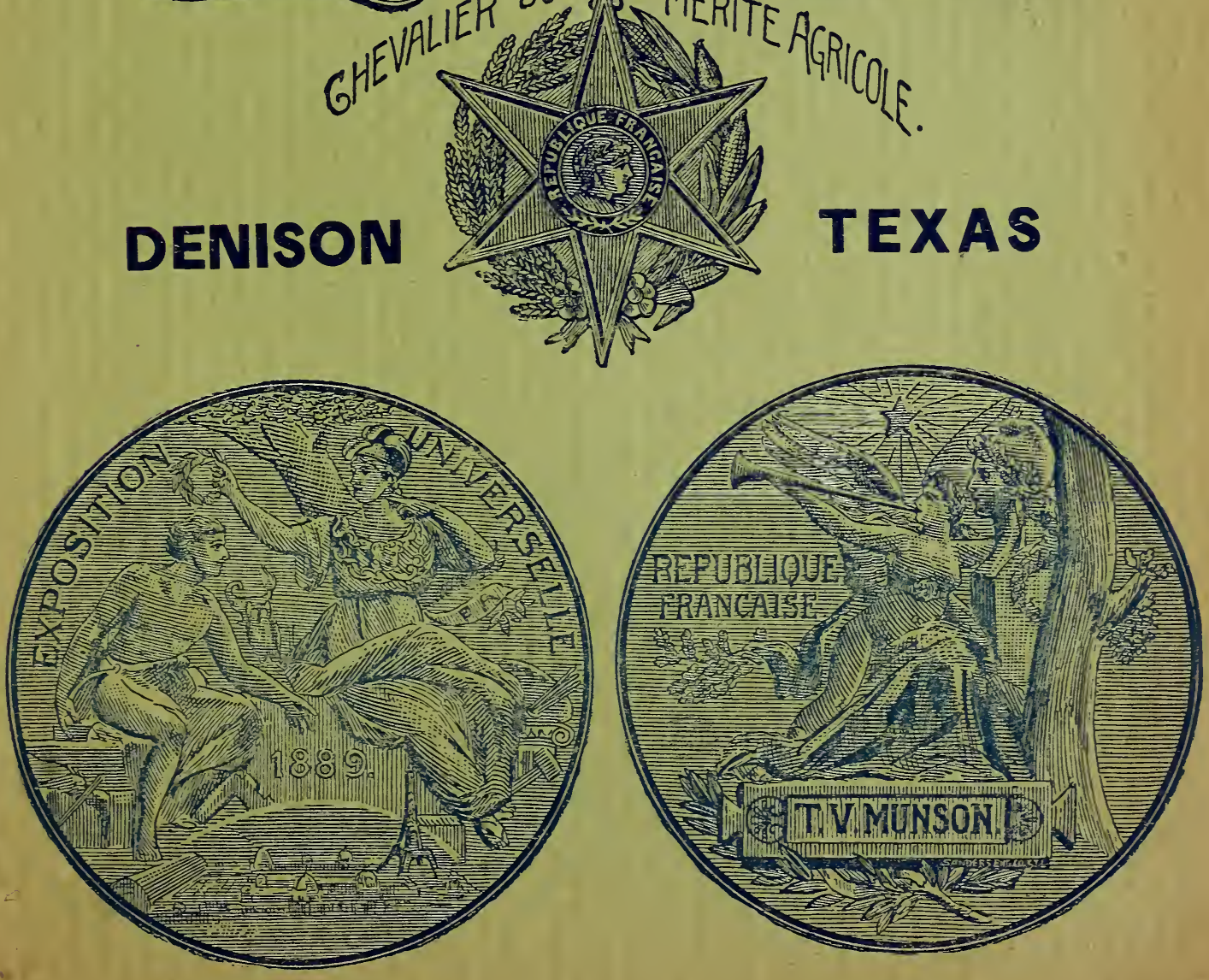


\title{
Horticultural Information.
}

\author{
A REQUEST.
}

Often persons to whom our Catalogue has been sent write us for information about what varieties succeed best in this and that locality, and for us to recommend a special list for their locality, and for various other horticultural information.

This Catalogue is specially arranged to answer all such questions as definitely as is possible for us to do, unless we should establish experimental stations in numerous parts of the country to get the special information. We have done as nearly that as possible, by visiting nearly every part of the entire country, taking notes of the successful and unsuccessful, and gleaning information from every reliable source, collecting and testing in our grounds nearly every promising variety brought out, and finally propagating the best only, and embodying brief, pointed descriptions of them, giving seasons, localities where most successful, etc., so that any diligent student of our Catalogue will find generally the very information we are so often asked to give. But if any one, after careful study of the Catalogue, fails to get the knowledge he wants, we shall be pleased to write it to him, if we know, or else refer him to works containing the knowledge.

This Catalogue is aimed to contain the very best information and list of varieties for the South and West that is possible to put in the space, su please do not lightly throw it aside. It embodies the best knowledge about varieties that twenty-two years of diligent work in the Southwest has secured.

No cultivator of fruits, trees or flowers can afford to be without some of the books mentioned below. Every horticulturist in Texas should be a member and attend the meetings of the Texas State Horticultural Society.

\section{A SMALL LIBRARY OF MOST USEFUL HORTICULTURAL BOOKS.}

These Books and Journals answer your questions in the best manner. If, however, neither the Catalogue nor the Books mentioned below cover your questions, we will answer them briefly, providing stamps are included for return postage.

So many of our customers write us for horticultural information (which we have ever most gladly give by letter, until the questions has become too numerous for us to longer thus answer) that we have, after careful examination, selected the following list of works, of most approved authorship, and arranged to niail direct to those ordering at publishers' price, given below. No discounts can be made on books.

Nearly every one of these books is profusely illustrated. The journals named are some of the highest standards.

American Grape Training. Including Munson's Trellis System. Prof. L. H. Bailey • \$o 75 Bailey's Field Notes on Apple Culture . . . . . . . . . . . . . . . 75 Bailey's Principles of Fruit-growing. Just published; a superb work . . . . . . . I 25 Black's Cultivation of the Peach. Including a chapter on Pears . . . . . . . I 50 Bushberg Grape Manual. Most valuable wurk on American grapes. Newly revised and enlarged.

Elliott's Practical Landscape Gardening. The planting of ornamental grounds. Fruits and Fruit Trees of America. Downing. A complete encyclopedia of promology Fuller's Small Fruit Culturist. Covering all classes of small fruits. . . . . . . . Fungous Disease of the Grape and other Plants, and Treatment. Scribner . . . . . Hand-Book of Tree Planting. Where, how, and what to plant for groves and forest . Harris' Talk on Manure. Treating the entire subject in a practical way . . . . . Henderson's Gardening for Profit . . . . . . . . . . . . . . . . Henderson's Practical Floricultare . Horticalturists' Rule-Book. Rules for the practical gardener. Prof. L. H. Bailey . . How to Improve Plants by Crossing and Hybridizing. Prof. L. H. Bailey..... How to Plant a Place. Illustrated. This splendid little work is given as a present to every customer who buys four dollars' worth or more of stock from us at single rates, in addition to other discounts offered on page $2 \ldots . . . . . .$. Hussman's American Grape Growıng and Wine Making. Latest revised edition... Irrigation Farming. Lute Wilcox. The best book on the subject; profusely illustrated Johnson's "How Crops Grow." Exceedingly important to one who would succeed. . Oemler's Gardening for the South. Treating of vegetables and fruits. . . . . . I 50 Quinn's Pear Culture for Profit. . . . . . . . . . . . . . . I oo Strawberry Colturist. Fuller . . . . . . . . . . . . . . . . 25 JOURNALS : American Agriculturist, weekly, \$i ; American Gardening, iveekly, \$I; Rural New-Yorker, weekly, \$I; Tezas Farm and Ranch, weekly; the best of all southern agricultural and horticultural journals. \$I; Southern Florist, monthly, \$I ; Horticultural Gleaner (of Texas), monthly, 5o cents. Any other horticultural journals desired sent at publishers' rates.

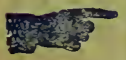

SEASON FOR SHIPPING AND TRANSPLANTING. We begin digging Strawberry Plants October I5, not earlier, and other stock November 1 , and continue almost uninterruptedly to dig and ship until March I5, November, December and February being the best months in which to transplant in the South. 


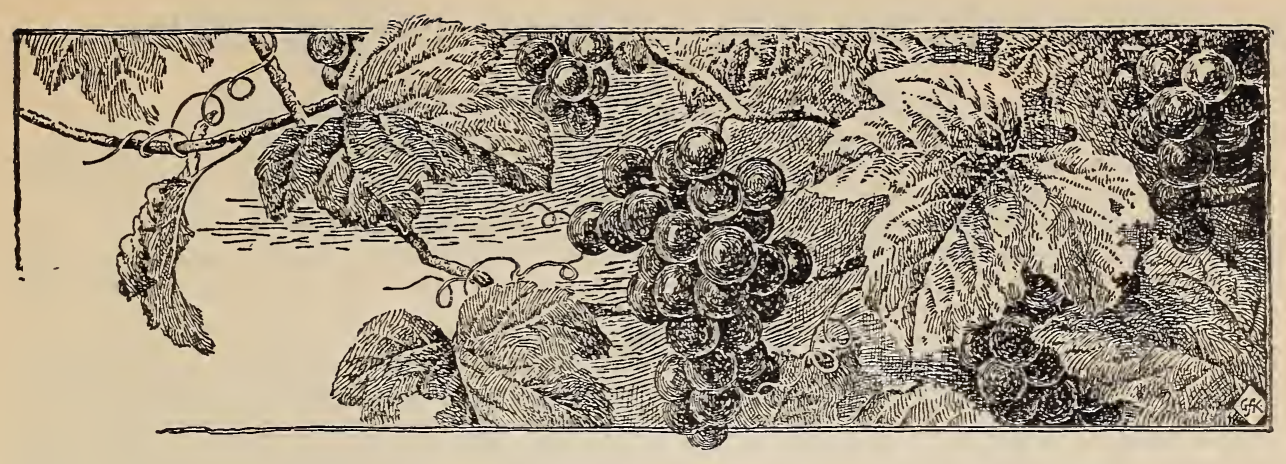

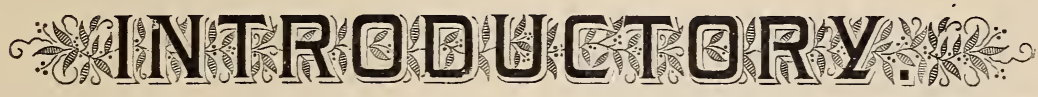

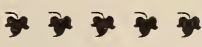

\section{To Our Dumerous, Intelligent, Discriminating Customers:}

Having always pursued the principle of giving plain, unvarnished discriptions, true to nature, and furnishing the very best of everything named, making every piece sent out a living advertisement of upright methods, our business has continued to rapidly expand, even through all the hard times. For all this splendid patronage we are profoundly thankful to our patrons, and are better prepared than ever to as carefully serve the increased patronage that we hope to receive the approaching season.

The following careful, truthful descriptions are of far more value in making successful selections than would be the grandest set of pictures that could be executed. Therefore, study the descriptions, and preserve this Catalogue, for it will be found a most valuable horticultural work of reference. Our methods of propagation are those pursued by the largest, most intelligent, and most successful planters of commercial orchards.

Those varieties throughout the Catalogue, outside our special list of Grapes, preceded by a star $\left(^{*}\right)$ were introduced by us after careful testing, and we are proud of them. They are generally making excellent records, and some have become recognized standards.

In some cases, varieties heretofore included in our Catalogue are omitted. Some of these are dropped, as others included are better of the same season, and of some we have no stock to offer this year; such may be inserted when we again have stock of them. Please do not order varieties not named in this Catalogue.

While we have a reputation for making a specialty of Grapes, we have by no means neglected other departments or classes of fruits in our line of business, All have had the same vigilant care in testing, selecting and propagation, so that we will be found up with the times in all things.

In our experimental department, we systematically test all new very promising varieties as they come out, and ourselves originate numerous varieties of grapes, plums, persimmons, etc. By carefully combining the best strains, and testing for a series of years in various localities, we from time to time introduce those proving superior to others in cultivation of the same season. We especially call attention to our new grapes, and to varieties throughout the Catalogue printed in CAPITALS.

TELEPHONE CONNECTION. We are in connection with the Southwestern Telephone and Telegraph Company, whereby our patrons can communicate directly with our office, and thus save time. Telephone orders attended to promptly. 'Phone 49. 


\title{
Please do not Fail to Read the following.
}

\author{
TERMS, CONDITIONS, SHIPPING, ETC.
}

Cash (by Draft, Money Order or Registered Letter) with order will secure prompt filling. No goods shipped unless cash or satisfactory security accompanies the order. Please use Order-Sheet in Catalogue.

To Secure Goods not wanted sent at once, send one-half the cost with the order. No reserve will be made otherwise, save to well-known and reliable parties, and by special agreement. Goods will be shipped "C. 0. D." only when one-half payment is sent with order, or to well-known and thoroughly reliable parties.

At prices named, goods are carefully packed in moss or straw, well baled or boxed, and delivered to forwarders here, after which our responsibility ceases, except for mistakes in filling, which must be reported immediately after receipt of goods, to admit of adjustment. A double system of checking is employed in putting up orders, so that mistakes are rare, and sometimes customers complain of an error and afterwards find it was their own mistake. Be careful, in unpacking, to note everything and immediately "heel-in" in moist soil till planted, or plant at once! Nover allow the roots to dry, or failure will most likely result.

Every care is taken to secure safe and prompt transportation.

It is always better to ship by Express, unless the amount of stock is large. Nursery stock goes byexpress at especially low rates.

Give explicit directions or onspuesi. uen such ate not given, we shall use our best judgment in selecting a route, but will not be responsible for loss thereby. Shipping facilities in every direction from Denison are unexcelled.

Customers will generally be most successfal in getting desirable assortments by leaving the selection, in part at least, to us, as we have much experience in testing and growing for market, but we desire everyone to have his or her choice, as nearly as possible.

It is to our own interest to give customers the best terms and selections possible. But we cannot prevent Drouths, Severe Winters, Early and Late Frosts, Insects and Rabbits, etc., from cutting, nor plants from dying by bad treatment in other hands, hence we never insure trees to live after leaving our possession, but do deliver good stock in good order, true to name. In case we fail in these, we replace at once or refund money. After stock is accepted we replace none that may die after planting.

We are responsible to all of our customers, and to them only, for the character of the goods, and to them or their forwarders, express and railway companies, we guarantee to deliver stock in good order, true to name. With such delivery our responsibility ceases.

It is a distinct agreement between us and our customers that in any case where stock fails to come up to specifications, we are liable only to replace stock or refund money received for goods in question. But no pains are spared to do a reliable business.

CAUTION.- We employ no traveling agents. Those claiming to be our traveling agents are frauds, and should be shunned. We have learned of a number of such operators, and have advertised them for the protection of planters.

CLUB ORDERS.-Many responsible persons get up Club Orders in their own communities, and send in to secure club rates. Such trade is respectfully solicited. Club rates will be given on application. This is the nearest approach we make to agency work.

SUBSTITUTION.-If it is not explicitly stated in the order that no substitution is permitted, in case the variety ordered is sold out, we shall consider permission to substitute granted, and then put in place of the variety ordered another, always with its correct name and one of equal or better value, unless such is not in stock, when the variety will be left unfilled and the money for it returned.

- Please do not order articles not named in Catalogue. We catalogue only what we thave for sale, and aim to sell only what we produce.

TREES AND PLANTS BY MAII.-Small fruit trees and shrubs, one-year grape vines, strawberry, raspberry and blackberry plants, can be sent by mail in packages of less than four pounds each at the rate of one cent for every two ounces. To cover this and packing, remit for every tree, shrub or grape vine, five cents each when six or less are ordered, and four cents each when six to twelve are ordered, and three cents each when more than twelve are ordered. For berry plants, remit ten cents per dozen, twenty cents for fifty, and thirty-five cents per hundred.

BUDS, CIONS AND CUTTINGS. - We do not offer for sale except where noted in the Catalogue.

PRICES. - When orders amount to less than $\$ 5$, the single rate given in Catalogue will be charged. These "single rates" do not apply to small fruits, such as Strawberries, Blackberries and Raspberries, except single dozens, or hundreds, when dozens are not priced. No discounts on small fruits at the thousand rates, unless as inany as 5,000 are wanted, then ro per cent off.

\section{DISCOUNTS ALLO MNED.}

(See second page cover, under A Small Library, "How to Plant a Place.")

Bills at Single Rates of over $\$ 5$ and under $\$ 10$ are entitled to additional selections at single rates to the amount of one-fifth of first selection, or I5 per cent off amount of bill.

Bills of Single Rates of $\$ 10$ to $\$ 20$ are entitled to one-fourth more additional stock at single rates, or 20 per cent off entire amount of bill.

Bills at Single Rates of $\$ 20$ to $\$ 40$ are entitled to one-third more additional stoek at single rates, or 25 per cent off entire amount of bill.

Bills at Single Rates of $\$ 40$ to $\$ 60$ are entitled to 40 per cent additional stock at single rates, or $33 \frac{1}{2}$ per cent off.

Bills at Single Rates of $\$ 60$ or more will be served at regular wholesale rates, which will be given on application. 


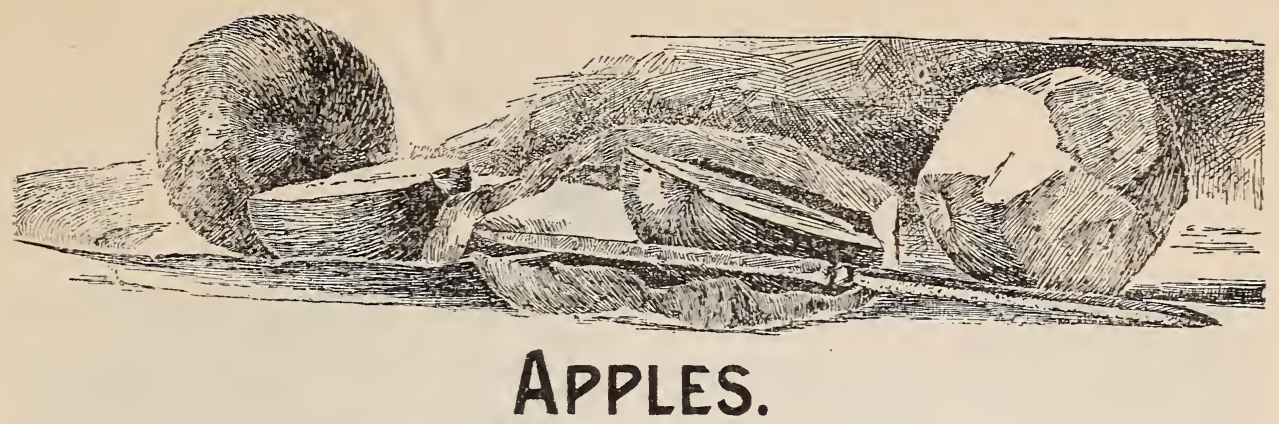

In order of ripening. 2 to $4 \mathrm{ft.,} 10 \mathrm{cts}$; 4 to $6 \mathrm{ft.,} 15 \mathrm{cts}$. See "Discounts Allorred," page 2.

This list has been well tested, and found uniformly and continuously successful in the Southwest. The varieties ripening in June and July are the most successful in South Texas. Late varieties do little or no good there. All the varieties named succeed well in Northern Texas and Indian Territory.

\section{June in Texas.}

Duchess of Oldenburg. Prolific, striped, medium ; good, tart ; market.

Early Harvest. Vigorous, abundant; yellow, large; good, tart; táble, cooking.

RED ASTRACHAN. Vigorous, productive; red, large; tart, market.

RED JUNE. Slow, prolific ; red, small ; good, tart; market, table.

FANNY. New, vigorous, productive ; red, large ; excellent ; market, table.

\section{July.}

Cooper. Vigorous, prolific; pale yellow, large; excellent, cooking, market.

SUMMER QUEEN. Abundant; striped, large; good, table, market.

GRAVENSTEIN. Vigorous, abundant ; striped, large; good, table, market.

AMERICAN SUMMER. Productive ; striped, medium; best, table, market.

Jefferis. Prolific; striped, medium; best quality.

\section{August.}

BLEDSOE (Texan). Very fine, prolific ; striped, large ; excellent, table, market.

Yellow. Horse. Very vigorous, abundant ; yellow, large ; good, culinary.

JONATHAN. Good grower, prolific; red, medium; fine, market.

Maiden Blush. Vigorous, prolific; cream-blush, large; fine, market, cooking.

CARTFR BLUE. Very thrifty, abundant ; striped, large ; fine, market, cooking. Ortley. Vigorous, productive; pale yellow, large ; excellent, table, market.

DOYLE. Of Texan origin. Large, striped; excellent, prolific.

\section{September.}

WEALTHY. Vigorous, profuse ; striped, large ; excellent, market.

Buckingham (Equinetely). Good, abundant; striped, large ; excellent, market.

Shannon. Strong, slow bearer; yellow, very large; best, table, cooking.

RED WINTER. Good, prolific ; red ; medium ; fine, table, market.

TWENTY-OUNCE. Very large, striped.

\section{October and Later.}

BRADFORD (Kentucky Streak). Strong, abundant; striped, large; very good, market.

WINESAP. Prolific; red, medium; very gnod, market.

BEN DAVIS. Hardy, vigorous, profuse ; striped, large; good, market.

Babbitt. Large, vigorous tree; large, fine, excellent.

*Rutledge. This variety originated in Travis Co., Texas. Tree vigorous and productive; fruit large, handsome, richly striped, resembling the Bradford somewhat, and of still finer quality than that splendid variety: it ripens shortly after the Ben Davis. In this, we believe, we have one of the most valuable of all Southern Apples. 50 cents. each.

GANO. Vigorous, prolific; bright red, large; good market; this variety is similar in every way to the Ben Davis, but of a rich red all over; very valuable.

TEXAS RED. One of the most highly esteemed Apples in East Texas. Large, striped; fine; excellent keeper.

Maverack Sweet. Vigorous, abundant; red cheek, large; very good, market or home.

NICKAJACK. Vigorous, abundant; large, striped; very good, market or home.

ARKANSAS BLACK. Vigorous, abundant; dark red, medium ; excellent, market.

KINNAIRD. Strong, spreading tree, prolific; red, large; a superb Southern winter Apple.

SHOCKLEY. Vigorous, abundant ; red cheek, medium; best keeper.

LIICBERTWIG. Vigorous, prolific red, medium ; very good keeper.

SHIRLEY.(Texan). Vigorous, prolific ; striped, medium; excellent keeper.

LOY. Vigorous, prolific; red cheek, large; best keeper.

MAMMOTH BLACK TWIG. A splendid, large, dark red Arkansas Apple.

Yates. Very vigorous, prolific; striped, small; cider or dessert; keeps very late ; best quality.

\section{CRAB APPLES.}

In succession. 20 cents each.

Whitney. Vigorous, prolific ; striped, large ; cider, jelly, preserves.

Hyslop. Vigorous, prolific; crimson, large, ornamental; preserves. 


\section{PEARS.}

In order of ripening. 30 cents each, except Lexington.

Andre Desportes. A handsome, goodsized, very early Pear.

*Lexington. This remarkable variety was found about the year ISS2, in a vacant lot in Lexington, Ky., by Mr. C. S. Bell, of that place. Finding the fruit so large and fine, borne on a very young seedling tree, he thought it worthy of preservation, and sent us wood for grafting. We have had it for about ro years, and find the tree very healthy, but of a dwarfish habit, grown on Pear root, and inclined to bear at two to four years of age. The fruit is about the same size, shape and color of Bartlett, but earlier by two weeks, and of about equal quality. So far no blight has ever attacked it. Very promising. We offer a few trees only, at present, at \$I each.

Clapp's Favorite. On Pear; prolific; red cheek, large; excellent, table.

HOWELI. On Pear; prolific; yellow, large; best, table, market.
Bartlett. On Pear; prolific; yellow, large ; fine, table, market.

Le Conte. On own roots; prolific; yellow, very large; good, table or market.

SECKEL. On Pear; prolific; brown, small; best, table.

Buffum. On Pear; prolific; brown, small ; fine, table.

BIRKETT. On Pear; very vigorous, never known to blight; an excellent fruit of good size ; comes into bearing slowly; valuable with age.

Superfine. On Pear; prolific; pale yellow, medium; best table.

ANGOULEME (Duchesse). On Pear, pale yellow; very large; good, market.

ANJOU. On Pear; moderate grower, moderate bearer; brown blush, medium; fine, table.

KIEFFER. On own roots ; very vigorous, prolific; yellow, very large ; excellent for canning; rarely blights or fails to bear.

\section{QUINCES.}

Quinces need very rich, deep, well drained soil; they are better for careful culture.

Meech. Very fine and prolific; none better in growth or quality of fruit. 30 cents each.

\section{Almonds.}

\section{0 cents each.}

Almonds succeed in irrigated regions of Western Texas, New Mexico, Arizona and California.

Languedoc. A leading variety ; grown for commerce.

Terragona. A large variety; also much grown for commerce.

Nonpareil. Produced by Mr. Hatch, of California.
Ne Plus Ultra. Produced by Mr. Hatch, of California.

Sultana. A standard and popular market variety.

Princess. Very fine, thin-shelled; rich, good flavor.

\section{APRICOTS.}

In order of ripening. 20 cents each.

Succeed best in limestone soils; bloom very early in spring. Should be treated like peaches.

Myer. Earliest; medium size, good; prolific.

EUREKA. Very early ; large, fine ; prolific.

Early Golden. Very early; medium, deep yellow; prolific.

ROYAL. Early; large, excellent; one of the very best.

Moorpark. Medium, large, excellent ; an old favorite.

CLUSTER. This valuable variety was introduced by A. M. Ramsey \& Son. It is

claimed to have never missed bearing any season since its introduction.

\section{Russian Apricots.}

ALEXANDER, BUDD and GIBB. The three best varieties of this strain.

\section{Japan Apricots.}

HUBBARD. This is remarkable for size, fine quality and vigorous trees, with broad, spreading heads.

\section{CherRIES.}

20 cents each.

Early Richmond. An old, popular,
$\begin{gathered}\text { English } \\ \text { Richmond; later. }\end{gathered}$ reliable variety; very productive. 


\section{FigS.}

25 cents each.

Adriatic. Very large, white; fine quality. The finest of commercial varieties, yet scarce in the United States.

Black California. Very large, dark

purple; bears the first year; a new and promising variety.

Smyrna. Large, pale purple; very prolific and fine.

\section{PEACHES.}

In order of ripening 3 to $4 \mathrm{ft}$, $10 \mathrm{cts}$.; 4 to $6 \mathrm{ft}$., $15 \mathrm{cts}$.

Each "ripening" extends over a period of Io to I5 days, and embraces white and yellow-fleshed, free and cling varieties, where possible. Nearly all the varieties have been critically tested by us along with numerous other kinds, in three successive test orchards, planted and fruited within the past $I 7$ years, in different soils and situations. Not a variety is included which has not been tested by experienced and critical orchardists, and pronounced valuable for the particular purposes and sections for which it is recommended. Desirable qualities in trees, as well as fruit, have been considered. Those varieties followed by the letter $a$ are recommended for amateur or family planting. In size and quality of fruit they are usually the very finest, but not prolific or firm enough, or of the right season for profitable planting, except in very favorable localities.

Those followed by $c$ are recommended for canning; those followed by $e$ are recommended for evaporating; those followed by $m$ are recommended for marketing fresh; those followed by $c$ e $m$ will make an excellent "all-purpose" variety.

While some of the following list do not succeed in the Gulf regions, the following have been found to do well there: Mamie Ross, Family Favorite, Oldmixon Free, Elberta, Bequett Free and Cling. The entire list succeeds well in all other parts of the Soutliwest. We Challenge the IVorld to Excel this List of Peaches.

\section{I.}

Ripening at Denison May 20 to June 10.

SNEED. $m$. Earlier, larger and better than Alexander; less inclined to rot.

ALEXANDER. $m$. Well-known old standard ; extra early.

TRIUMPH. $m a$. Large yellow freestone, mostly covered with red; most attractive extra early Peach yet produced. Will certainly become very popular as a market fruit. 50 cents each.

Greensboro. $m$. Of the same class and description as the Mamie Ross, ripening earlier. Originated in North Carolina. New. 50 cents each.

\section{II.}

TEXAS (Texas King). Of the same class and character with the Mamie Ross; better quality. Origin east Texas.

* MISS LOLO. a m. A perfect freestone; fine quality; blush, white flesh; prolific.

MAMIE ROSS. a m. A very large blush, white flesh; semi-cling ; prolific; very valuable.

HYNES' SURPRISE. $m$. True freestone when ripe; resists rot better than Hale's Early, which it resembles.

* BISHOP. $m$. Very large, crimson, white flesh, free; a valuable market sort, sure and prolific.

Alice (Haupt). $m$. Chinese Cling, seedling; prolific, large, fine.

\section{III.}

Ripening at Denison June 10 to July 5.

RAY. $c$ e $m$. A noted east Texas variety; even larger and finer than Mamie Ross. Similar otherwise.

Yellow St. John. a $c \mathrm{~m}$. Where it succeeds well it is exceedingly profitable. Does well in California and eastern and western Texas. Tender in bud here, like Crawford.

General Taylor. a $m$. Large: flesh blood red, crimson all over; cling of Indian Blood type; productive.

Fldred. a $m$. A crimson cling of immense size. Origin southern Texas.

MOUNTAIN ROSE. $c e m$. Large, round; white flesh, red cheek; free.

\section{IV.}

* FAMILY FAVORITE. $m c e$. Large; white flesh, red cheek; free, sure, prolific; seedling of Chinese Cling. This is making a most favorable record every where.

Jennie Worthen. $c$ e m. Medium to large; yellow, free, rich crimson cheek; sure.

MRS. BRETT. $m c e$. Similar to Oldmixon Free, but about a week earlier ; sure, prolific.

Foster. a e c m. Earlier and finer quality than Early Crawford; very handsome.

\section{V.}

Ripening at Denison July 5 to 20.

GEN. LEE CLING. a $m$. Seedling of Chinese Cling, but earlier and more prolific ; better.

Crawford Early. a. Tender in bud; an old, valuable standard variety. Fine in IVest Texas.

OLDMIXON FREE. $m c e$. Large, white flesh, red cheek; fine, prolific, sure. An old "stand-by."

ELBERTA. $m c e$. Very large, yellow, red cheek, free, firm, sure, prolific; best of all. For vigor, certainty and abundant bearing, this variety has no superior; for fine appearance, good shipping qualities and ready selling, for canning and evaporating, it stands without a peer. It cannot be too extensively planted. 
PEACMES, continued.

SUPEP.B. (Name changed from June Rose). $m c e$. Seedling of Early Rivers, crossed with Mlountain Rose. Pure freestone; white flesh, red cheek; a very prolific and profitable Peach ; finest quality.

Crosby. $m c e$. Large, yellow freestone, sure bearer, and prolific.

Chinese Cling. $a$. Largest size, oblong; greenish cream, faint blush.

* Utah Free. c e m. Large, prolific; rich yellow; valuable.

*Utah Cling. $m$. Large; prolific; yellow, red cheek. Introduced by us in I893.

* SHIPLER. cm. Yellow, cling; supposed cross between Chinese Cling and Crawford, produced by A. L. Shipler, of Denison, Texas. Valuable ; resembles the Elberta, except being a cling. $50 \mathrm{cts}$. each.

\section{VI.}

Ripening at Denison July 20 to Angust 10.

SYLPHIDE. $m c$. Cling; large; white flesh, red cheek; prolific, sure; seedling of Chinese Cling.

BEQUETT FREE. $m c e$. Largest size; white flesh, red cheek; productive, firm, superb; possesses Chinese blood; a sure bearer.

Orange Cling. $c m$. Large, clear, yellow ; sweet, rich, juicy; prolific.

IRUID HILL. $m e c$. Large, white flesh, red cheek; free ; prolific ; old reliable kind.

STUMP. $m e c$. Large, white flesh, red cheek; free; reliable.

BEQUETT CLING. c m. Very large, white Hesh, red cheek; productive, fine; as large as Chinese Cling, and possesses some Chinese blood.

OLDMIXON CLING. $m c$. An old standard variety; large, white flesh, blush.

\section{VII.}

Ripening at Denison August 10 to 25.

Columbia. cem. Large; dull orangeyellow, mottled with red; free; sure.

* Scruggs. $c \in m$. Large; similar to Picquet's Late, but earlier; valuable.

CROTHERS. $m e c$. Large; white flesh, red cheek; best, productive ; superior to Ward s Late.

Walker. $m e c$. Largest; white flesh, blush cheek; an old standard kind.

* RAISIN. $a m$. Of the Indian Cling type, crossed with Heath. Large, juicy, prolific; splendid. The finest in quality of any cling known to us.

\section{VIII.}

RINGGOLD. $c m$. A greatly improved seedling of Heath Cling ; superb.

Picquet. $m c e$. Very large; yellow, with red cheek; free; sure, prolific.

SALWAY. $m c e$. Similar to Picquet ; sometimes follows it, and sometimes precedes it.

*Crimson Beauty. $m c$. Very large; white flesh, crimson surface ; cling ; prolific.

\section{IX.}

Ripening at Denison September 10 to 25.

Wonderful. $c e m$. A remarkably fine, yellow freestone, of the Smock type.

HENRIETTA, or Levy. $m c$. Very large, cling; yellow, crimson cheek; sure.

*BONANZA. cem. Very large; white flesh, red cheek; free; prolific, vigorous.

LONOKE. a m. Large, yellow; cling ; prolific; flowers large; late, sure.

*Topaz. c e m. Large, yellow; free ; red cheek; prolific; flowers large, late.

*Cobbler. c e m. Large yellow; free ; prolific, vigorous tree; valuable.

\section{X.}

Ripening at Denison into 0ctober.

*Barnes. a $m$. A fine, very late yellow cling of Indian type. Originated in Bell county by Barnes Parker.

*BELL'S OCTOBER. c e m. Large, rich yellow, red cheek; freestone ; of finest quality. Originated by Hon. C. C. Bell, of Denton county, Texas. 50 cts. each.

*Success. e c m. Prolific, sure; latest yellow freestone; large, excellent. Originated in our grounds, and offered with confidence in its merits. $50 \mathrm{cts}$. each.

\section{Plums.}

Unless otherwise noted, 20 cents each.

This list is superb. Varieties of each class generally stand in order of ripening, and all succeed well nearly everywhere.

\section{CHICKASAW Varieties.}

Bloom very early.

Lone Star. Medium grower; red, large, good; abundant.

*Emerson. Moderate grower ; red, large, good quality; heavy bearer.

MUNSON. Originated by G. Onderdonk, Victoria, Texas. Tree vigorous, spreading; sure and prolific; large, round, red; excellent, profitable.

*TRANSPARENT. Excellent grower; yellow, above medium; good, abundant.

\section{CHICKASAW VARIETIES OF THE WILD GOOSE TYPE (P. Hortulana.-BAILEY).}

Bloom early to medium.

*CLIFFORD. This splendid Plum was produced by Mrs. Clifford, of this city, from seed of Wild Goose. It is larger than Wild Goose, pear-shaped, red, meaty, with fine, pineapple flavor. $50 \mathrm{cts}$. each.

WILD GOOSE. Vigorous ; red, large, very good; abundant when pollinated by other varieties flowering at the same time. 
PIUU⿴囗十 $\mathbf{\text { I }}$, continued.

WOOTTON. Good grower; red, medium, very good; prolitic, sure. Trees of this planted near or among. Wild Goose pollinate its flowers, causing it to bear well.

Whitaker. Improvement in tree and fruit on Wild Goose, of which it is a seedling, by T. J. Whitaker, of Smith Co., Texas.

MILTON. Wild Goose cross on Americana. Better than IVild Goose, equally as large; handsome and productive; red; excellent.

CHARLES DOTVING. Wild GooseAmericana cross. Very vigorous, healthy tree; fruit large, handsome, excellent. One of the best of the IVild Goose type.

\section{PRUNUS RIVULARIS Varieties.}

Bloom very late.

*Nimon. Hybrid, produced by us, of Wayland pollenated by Wild Goose. Tree very vigorous and healthy, productive ; fruit large as Wild Goose; crimson, with white dots. very handsome, ovate, firm, meaty and of excellent quality. A Plum of much promise. Now offered for the first time. Si each.

Wayland. Vigorous; crimson, medium, good, firm; very prolific; sure.

GOLDEN BEAUTY. Vigorous; vellow, medium, good; free, very prolific ; unfailing.

We have certainly identified Wayland and Golden Beauty as belonging to Prumus Rivularis (Scheele), which grow native on the streams of western Texas. Golden Beauty was found wild on the Colorado River of Texas. We have grown many seedlings from seed gathered in West Texas of the P. Rivularis alongside of Wayland and Goiden Beauty proving beyond doubt that they belong to this species, which is one of the best in the United States for hardiness, productiveness and good quality.

\section{AMERICANA Varieties.}

All this class flower very late, and are sure fruiters.

CHENEY. Vigorous, prolific, large, red; earliest of this class; excellent.

WFA VER. Vigorous ; red, good, prolific ; sure, well tested, profitable.

HAMMER. Vigorous, upright, prolific ; large, red, meaty, excellent; nearly freestone.

FOREST GARDEN. Vigorous, red, large ; excellent, prolific, sure.

HA WIKEYE. Very highly recommended as one of the best of this class.

New UIm. Very large, red, firm; excellent.

ROCKFORD. Exceedingly vigorous, prolific; large; red; excellent.

Wilder. One of the newer varieties of great promise. 50 cents each.

Wyant. New; highly recommended by those who have fruited it.

*NEWTON. Vigorous, healthy; very prolific, unfailing cropper; very large, red; freestone of best quality; new. 50 cents each.
JAPANESE Varieties. (Prunus triflora.)

Yosobe. Spreading, prolific; medium, purple; earliest.

ABUNDANCE (Botan). Vigorous, upright; large, purple, good; very prolific, sure; best of all Japan varieties.

Ogon. Very large, pale yellow; freestone; fine quality when fully ripe.

Berckmans (Sweet Botan). Large, purple, prolific; of fine quality.

BURBANK. Very vigorous, spreading, very prolific; very large, purple, profitable.

DOUGLAS (Hytankayo). Strong, upright tree; fruit very large, crimson, with white bloom; excellent, prolific, valuable.

Normand. Vigorous, prolific tree; fruit when large, broad heart-shaped, rich yellow when fully ripe; very firm and meaty, of finest quality; very valuable. 50 cents.

SATSUMA. Good, healthy tree; fruit large; blood red in surface and flesh.

Wickson. Vigorous, upright tree; a hybrid produced by Luther Burbank between Kelsey and Burbank; immensely large; purplish red; of finest quality. 50 cents.

Hale. Tree most vigorous; fruit very large; orange, mottled with cherry-red; quality equal to the Imperial Gage. Prof. L. H. Bailey pronounces it the best in quality of all the Japan Plums. One of the finest of all Luther Burbank's productions. \$I each.

\section{EUROPEAN Varieties. ( $P$. domestica.)}

Clyman. Large, purple, prolific; very fine.

Giant. Produced by Luther Burbank; largest of all Prunes; very vigorous, purple, fine quality. 50 cents each.

Pacific. This is a new Prune of the Pacific coast; of first-class merit as a commercial Prune. 50 cents each.

Silver Prune. Very large, pale yellow.

Tragedy. Large, dark purple; very rich and sweet; freestone; very valuable as a shipping Plum. 50 cents each.

The above Prunes are recommended for regions where European Plums are known to do well, as in Western Texas and New Mexico, where rot and curculio do not prevail.

\section{ASIATIC Varieties.}

Pissard, or Purple-leaved Plum. Foliage and froit always rich purple, and on this account more planted for ornament than for the fruit.

Simon ( $P$. Simonii). A very peculiar species of Plum. Tree upright, vigorous ; flowers very early, and on this account not successful where late frosts prevail, but otherwise a most beautiful, delicious and valuable fruit. Very large, flattish appleshaped, of rich vermilion color when fully ripe; very fragrant and delicious; a firm and fine shipper. Succeeds in localities in Vest Texas, New Mexico, Arizona and Califurnia. 


\section{MULBERRIES.}

4 to $6 \mathrm{ft}$, $15 \mathrm{cts}$; 6 to $8 \mathrm{ft} ., 20 \mathrm{cts}$; large, $25 \mathrm{cts}$.

HICKS' RVERBEARING. Profuse bearer of fruit for three months; fine grower for shade; the best of all trees for the fowl yard, as the fowls greedily eat the berries.
Victoria. The finest-fruited Russian Mulberry yet produced; very fine.

Downing. A larger, better berry than Hicks'; not so prolific, and not so hardy.

\section{BLACKBERRIES.}

In succession.

\begin{abstract}
*Spalding. Origin Gonzales county, Texas. Very vigorous, quite thorny, and holds its foliage till very late in the fall; will probably be evergreen in the Gulf regions; it bears abundantly of very large, most excellent fruit, ripening with or before the Early Harvest Blackberry-about the same time with Dewberries. It is the largest and earliest southern Blackberry known to us. We do not recommend it for regions where winter temperature goes below zero. Io cts. each, \$I per doz., $\$ 5$ per Ioo.
\end{abstract}

EARLY HARVEST. V'igorous, upright, few weak thorns; very prolific; medium size, firm; profitable market. $50 \mathrm{cts}$. per doz., \$2 per IOO, \$10 per I,000.

DALLAS. Very vigorous, drooping, thorny, productive; large, fine. This is proving to be a very valuable market variety. 50c. per doz., \$2 per IOO, \$10 per I,000.

Minnewaska. Similar to Kittatinny, but' regarded as still better and not subject to rust; new. 50 cts. per doz., $\$ 2.50$ per roo.

Erie. Vigorous, upright, moderately thorny, prolific; very large and fine. 50c. per doz., \$2.50 per I0O.

\section{DEWBERRIES.}

MIAYES (Syn., Mayes' Hybrid, A:istin's Improved). This originated at Pilot Point, Texas; we have the genuine. It is exc :edingly large, fine and early; prolific. roc. each, $\$$ I per doz., \$5 per Ioo.

\section{RASPBERRIES.}

Palmer. This comparatively new variety is considered the largest and best of the early black caps. \$I per doz.
Kiansas. A very large, excellent-fruited black cap; one of the best for a:dry, hot climate. \$I per doz, \$5 per Ioo.

\section{STRAWBERRIES.}

25 cts. per doz., $\$ 1$ per $100, \$ 4$ per 1,000 , unless otherwise noted.

MICHEL'S EARLY. Earliest of all ; large; vigorous, perfect flower; a fine pollinator for other kinds.

CRESCENT. Early, prolific ; bright ; excellent market ; pistillate ; needs Michel's Early to fertilize it.

Captain Jack. Used here as a fertilizer of Crescent, and makes the best market companion for it; it is large, crimson, firm, good and very productive.

BUBACH NO. 5. Large, handsome; productive, valuable; very successful here; pistillate.

Greenville. Large, very prolific; fine plant; has made a fine record wherever tried; pistillate. Parker Earle will be an excellent variety to plant alternately with Greenville.
*PARKFR EARLE. Still leads every other variety. Plant robust, free from disease, stooling heavily, and renewing itselt sufficiently by strong runners. It is a model in make-up; endures the extremes of heat and cold remarkably well. Berry regular, uniformly large, conical, with a neck glossy scarlet-crimson, ripens all over; flesh firm, crimson, no hollow core ; seeds golden, becoming crimson, prominent, protecting in handling; quality excellent. Flowers perfect, always setting perfect fruit, which is borne in the greatest profusion, the rate of 16,000 quarts per acre having been gathered. The fruit carries well, and brings the very highest price in market. 50 cts. per doz., \$I per I00, \$3 per 500, \$.5 per I,oco. 


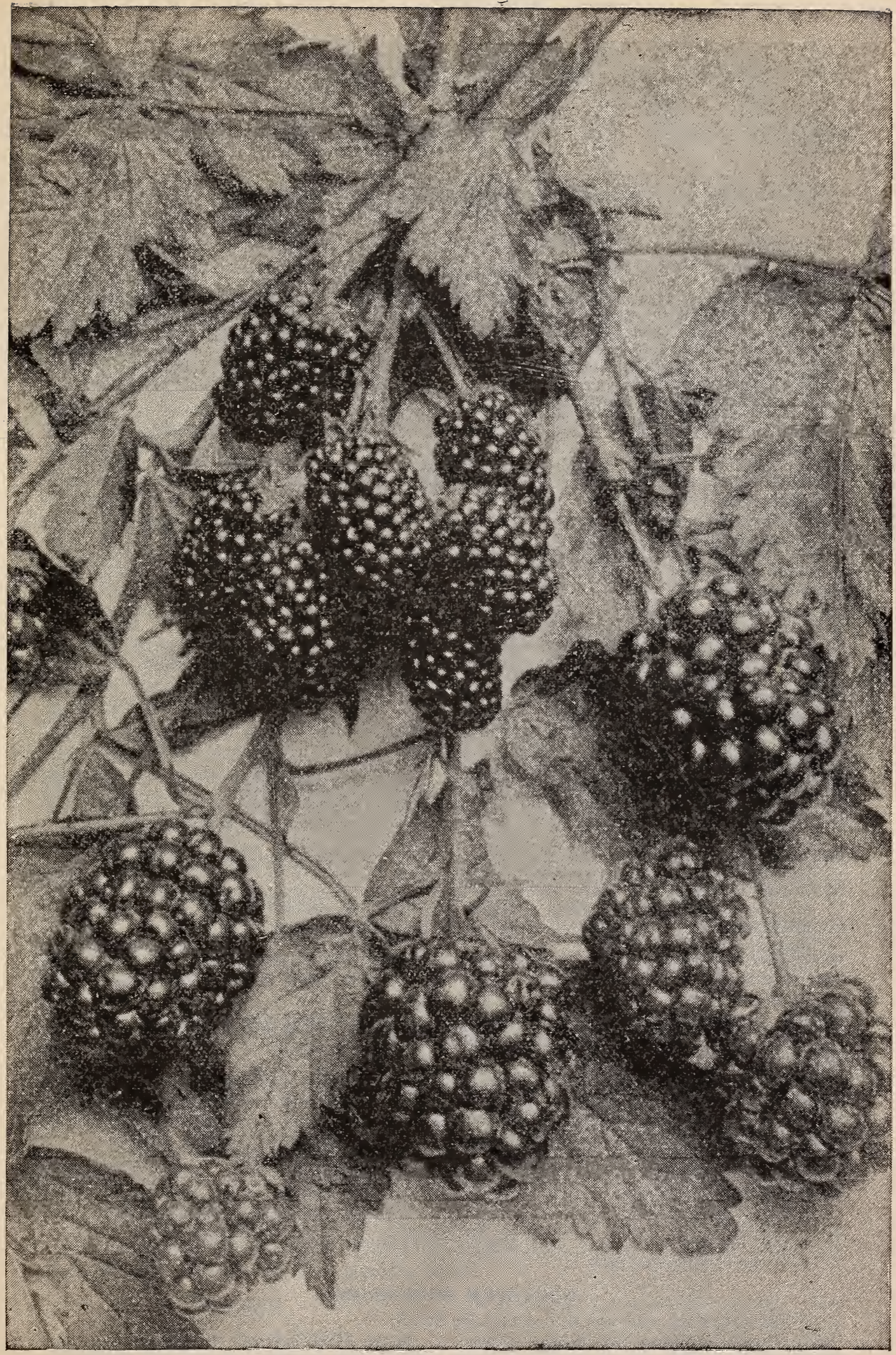

MAYES DEWBERRY AND EARLY HARVEST BLACKBERRY.

From Photograph, exact life size

It requires seven times as many of Early Harvest as of Mayes to fill the same measure, by actual trial, 


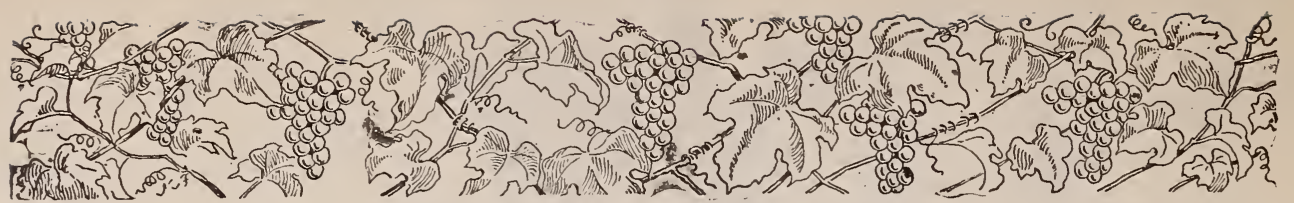

\section{GRAPES.}

We lead all competitors in this field.

\section{STANDARD LIST.}

In succession. Have a large stock of finest quality. This list contains the best and most successful; have tested all these, with hundreds of others. Flowers perfect, and will bear alone, unless otherwise noted; when pistillate, they need a perfect-flowered kind planted near. With irrigation in West Texas and westward all varieties in the list succeed. East of the Iooth meridian, the Bordeaux mixture spray will enable many varieties to succeed that without it fall on account of the rot and mildew. In moist regions all varieties do better to be treated with Bordeaux spray.

Champion. Large, black; poor quality, market; vigorous, prolific; Texas

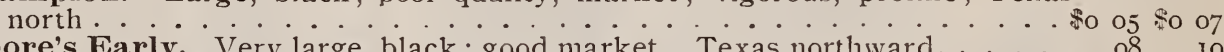

Moore's Early. Very large, black; good market. Texas northward. · · $\cdot$.
GREEN MOUNTAIN. New; above medium, white; prolific, good. Texas northward.

MOORE'S DIAMOND. One of the finest, white American Grapes; new. Texas north .

IVES. Medium, black; fair market, wine; free from disease. Texas north . .

Perkins. Large, pink; fair market, prolific, healthy. Texas northward...

Brighton. Large, red; fine table, market. wine; pistillate. Northward . .

Norfolk. New ; large, red; fine table and market, wine. Texas northward .

Lindley. Large, red; very good table and market; pistillate flower. Nortlıward

Salem (Rogers' No. 53). Bunch and berry large, dark, chestnut red, sweet, rich and tender, good shipper, vine vigorous.

Agavam (Rogers' No. I5). Similar to Salem, with still larger berries, darker red; peculiar, agreeable flavor; vigorous, prolific

Lady Washington. Very large, pale red; very fine table Texas north.

Empire State. Large, yellow; fine table; prolific, rots, drops. Texas north . Worden. Very large, black ; good market; "Improved Concord" . . . . . .

NIAGARA. Large, white; very good table, market; successful.

Martha. Large, white; table, wine; for same region with Concord . . . . .

CONCORD. Large, black; table, market. Texas northward. Ripens un-

Eaton. A seedling of Concord, with large clusters and enormously large, black

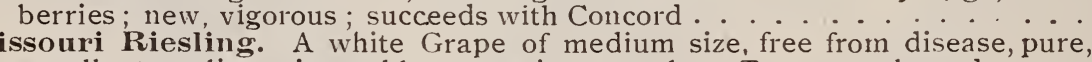
excellent quality, wine, table; sometimes cracks. Texas northward . . . .

CATA WBA. Cluster and berry large, dark red; juicy, sprightly; fine, fine for market, table and wine.

Excelsior. Large berry and cluster, red, meaty; best table; feeble . . . .

JEFFERSON. Large, red berry; large cluster; best table, market. Texas

Diana. Large, red; fine table, market, wine. Central Texas northward .
Triumph (Campbell's). Very large, white; best table. Texas to Missouri .

Goethe. Very large, pink; fine table. North Texas to Missouri .......

Highland. Vigorous, prolific; very large cluster and berry; black; fine. . . .

Norton (Cvnthiana). Small, black; fine, red wine. All Southern states · $; ~$
Jacquez (Black Spanish, Le Noir, "Blue French"). Small, large cluster, black;

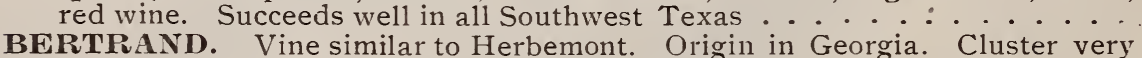
large ; berry small to medium, dark purple, red juice, fine, sprightly. Even successful than the Herbemont in the South. New ...........

HERBEMONT (McKee, Bottsi, "Brown French"). Small, large cluster, purple ; finest quality, table, wine; best old Grape in Southwest Texas . . .

PULLIAT. Originated in France from Herbemont, than which it is larger, even better, of same color, later, very prolific, less subject to rot: succeeds wherever the Herbemont does.

\section{SOUTHERN MUSCADINES.}

Succeed in deep, rich soil throughout the South.

Flowers. Medium to large, black; good. I5 cts. each.

THOMAS. Very large, black; good wine; I year old. I5 cts. each.

SCUPPERNONG. Large, brownish yellow; good wine; I year old. I5c. each.
Male Muscadine. If planted near the above, this variety renders the three varieties named very fruitful anywhere in the South. Without such pollinators planted nearby they are unfruitful. $25 \mathrm{cts}$. each. 


\section{VINIFERA VARIETIES.}

10 cents each, unless noted otherwise.

These succeed in far South and West Texas, especially with irrigation, equally as well as in California, but fail entirely in Central and East Texas, owing to phylloxera, rot, mildew, etc., but by grafting on resistant roots and spraying with Bordeaux mixture, succeed in all but extreme North Texas, and with winter protection can be fruited there.

We have in our Vineyard, on sandy soil, the following list, growing and fruiting successfully, selected from among a large number of the finest French, Spanish, Hungarian, Italian, siciliary and Persian varieties. Some are of recent importation. We have no grafted vines for sale, but can supply cuttings of best resistant stocks for the South and California by mail at $\$ 2$ per 100 .

The remarks with reference to inildew and rot are of vines in open ground, not sprayed, at Denison, Texas.

CALABRIAN. (Italian.) Of Muscat type; vigorous, healthy, some black-rot; cluster very large, compound; berry large, roundish, yellowish, meaty, juicy, fine; table, market, raisin.

Carminet du Medoc. (Cabernet, French.) Vigorous, healthy vine; fruit subject to black rot ; cluster medium ; berry small to medium, black; season medium; juicy, sprightly, fine for wine.

CRUJIDERO. (Sicilian.) Vigorous ; little mildew and rot ; cluster and berry very large; berry ovate, yellow, meaty, equal to Malaga for shipping; excellent quality. $50 \mathrm{cts}$. each.

FEHER SZAGOS. (Hungarian.) Very vigorous, healthy; fruit subject to rot; Persian type; cluster very large; berry cylindrical, ellipsoidal, curved like Cornichon; white, meaty, very fine; table, market, raisin.

FAVORITA. (Italian.) Vigorous, healthy, some mildew ; cluster large ; berry large, roundish, yellowish, translucent; juicy, sprightly, rich. $50 \mathrm{cts}$. each.

GOLDEN CHAMPION. (Californian.) Vigorous, some mildew and rot; cluster large; berry large, ovate, yellow, late, fine, juicy; table, market.

GRIESE DE PIEDMONT. (Italian.) Vigorous, healthy, very little mildew or rot; cluster very large, compound; berry large, purplish black, meaty, juicy, very fine; table, market, white wine. 5oc. each.
Mission. Vigorous, subject to mildew and rot; cluster long, straggling; berry small to medium, pale to dark red; very sweet and juicy.

MALAGA.

healthy ; cluster (Spanish.) Vigorous, ; Cluster very large; berry large

OLIVET DE CADINET. (Italian.) Vigorous, some black rot; cluster large; berry large, ovate, purplish black, meaty, juicy ; table, market, wine. 50 cts. each.

QUAGLIANO. (Sicilian.) Vigorous, prolific, little mildew and no black rot; cluster large; berry large, round, grayish purple, meaty, juicy, fine, late; table, market. 50 cts. each.

Romania. (Italian.) Vigorous, subject to mildew and rot; ciuster very large; berry very large, purplish black, roundish ovate, late; table, market.

SAUVIGNON JAUNE. (French.) Vigorous, healthy, little mildew and rot; cluster large, compact; berry medium, yellow, meaty, tender, early ; table, white wine.

Verdelho. (French.) Vigorous, healthy, fruit rots; cluster large ; berry large, ovate, yellowish, meaty, juicy; table, market.

VIOLET CHASSELAS. (French.) Vigorous, mildews and rots; cluster large ; berry large, ovate, violet, beautiful, superb quality ; table, market, wine.

ZINFANDEL. (Hungarian.) Vigorous, healthy vine, fruit rots ; cluster large, compact; berry medium, round, black, juicy, fine; table, wine.

\section{NEW CREATIONS IN AMERICAN GRAPES.}

\section{T. V. Munson's Hybrids and Seedlings.}

It has not been our object to foist upon the public a lot of worthless novelties, but we have undertaken, in an honest, progressive spirit, to originate, test and introduce a succession of varieties possessing the best combination of native blood possible, to furnish the country what it greatly needs; but has never had-varieties of the most successful, valuable character, covering the entire Grape season in the South from July I to November. Having better material and better knowledge than ever before from which to produce valuable combinations, we yearly grow some additional hybrids for special purposes and regions. A few of the best of these may be offered for sale in due time, in case we think them real improvements over anything at present possessed. As a money venture, we never expect to regain expenses in the matter of production of new varieties, as it is a long, expensive, little-appreciated process; but we take a pleasure in it, and an ambition to do something that will bless the race long after we have ceased to work.

\section{PRESLY.}

The Earliest of all Grapes.

This is a seedling of Elvira crossed by the Champion. The vine is strong and healthy, covered with a healthy dark green foliage. It is the first of our Grapes to ripen, and on this account it is a profitable variety. The size of the cluster and berry is that of the Delaware and resembles the Delaware; even more attractive in the basket. The quality is good, far above that of Champion. The berry is juicy and the pulp tender. For an extra-early market Grape that would give 
Grapes, continued.

satisfaction, we could recommend none better than this. The vine is prolific, always setting a full crop. Free from all diseases. $50 \mathrm{cts}$. each, \$5 per doz.

\section{BRILLIANT,}

The coming great, early, red, market and table Grape for Texas northward.

(From a photograph, life-size; have produced much larger clusters than the one shown in cut. See page $x_{5}$.)

This is a seedling of Lindley crossed by Delaware, produced in I883. The vine is healthy, vigorous and hardy, having endured the wiaters of New York and Ohio with impunity. It ripens just before the Delaware, is very prolific; berries and clusters as large as Concord; compact, translucent red, similar to the Delaware; quality about the same as Delaware, with less pulp; seeds one to three; skin thin and tough, berries adhere firmly to peduncle, making it a splendid early market Grape, suitable for long shipments, and it will command the highest price; it makes a fine white or amber wine. Shipped it over I, ooo miles to market in fine order, and received best price on the market. It has received unreserved praise everywhere it has been tested-in Florida, Georgia, Nerv Jersey, New York, Ohio, Kentucky, Missouri, Texas, Colorado and Connecticut. It mildews some in wet seasons in New Jersey and Michigan, near large bodies of water, but Bordeaux spray corrects that. $25 \mathrm{cts}$. each, $\$ 2.50$ per doz.

\section{BELL.}

A hybrid of Elvira with Delaware. Vine vigorous, healthy, free from mildew and leaf-folder, very hardy, a good, sure producer; cluster medium, cylindrical, often with a shoulder, fairly compact; berry medium, round, greenish yellow, rarely attacked with black rot; skin thin, sufficiently tough to prevent cracking under ordinary weather changes; pulp rather tender, juicy, very sweet and agreeably flavored; ripens just before Concord. We consider it a superior Grape to the Green Mountain. Successful in Texas northward. 50 cts. each, \$5 per doz.

\section{ROMMEL.}

Produced in 1885 by crossing the Triumph upon Elvira. Vine very vigorous, free from disease, not attacked by the leaf-roller; clusters medium, simple or shouldered, compact, handsome; berry medium to large, yellowish white, translucent; skin thin and tough; pulp melting; seeds few and small; quality best, pure, sprightly, vinous; season about the same as Delaware; the vine is very hardy to resist cold or heat, and is very productive. We recommend this variety for extensive trial North as well as South, as a very superior Grape. The crop on 300 vines at five years of age averaged over I5 pounds each, and brought the highest market price. It makes fine white wine. Texas northward. 25 cts. each, \$2.50 per doz,

\section{BEACON.}

\section{"The Southern Concord."}

A hybrid of a very large-clustered, largeberried "Texas Post-Oak Grape"' (Vitis Lincecumii) of good quality, excelling Concord. Vine vigorous, with dark, glossy green leaves of excellent texture and health; leaves out and flowers later than Concord and ripens earlier; cluster large, long, cylindrical, often with a shoulder; berries closely resemble those of Concord, but average larger, some being one inch in diameter, and the bloom is somewhat heavier; the fruit has not the rank muskiness of Concord, but a very agreeable tuberose odor; skin tougher; pulp rather tender, meaty, of a somewhat similar, yet better quality than Concord; seeds three to four, above medium. The vine is exceedingly prolific, and carries its load with ease. This Grape, we believe, will succeed almost anywhere that the Concord will thrive, and in much of the dry, hot southern country where Concord is practically a failure. The fruit is less attacked by rot than that of Concord, and ripens perfectly even, while Concord is very irregular in that respect in the South. $50 \mathrm{cts}$. each, $\$ 5$ per doz.

\section{R. W. MUNSON.}

A hybrid of "Big Post-Oak" with Triumph The vine is very vigorous and healthy, setting and maturing a heavy crop, enduring drouth remarkably well; cluster large, cylindrical; berry large, black; seeds two to three, small; skin thin and tough; pulp tender and of excellent quality. $50 \mathrm{cts}$. each, $\$ 5$ per doz.

\section{DR. COLLIER.}

A hybrid produced from a very large, fine Post-Oak Grape, pollinated by Concord. Leaves out and flowers late; very productive and vigorous; hardy; clusters large, conical, handsome; berries large, red, becoming dark purple, very beautiful. Much less subject to rot than Concord; skin thin, does not crack; pulp very juicy, sprightly, with an agreeable, perceptible Concord flavor; hangs on longer after ripening without losing flavor, and will probably mase a much better wine than Concord. Ripens just after Concord. Missouri southward. $50 \mathrm{cts}$. each, $\$ 5$ per doz.

\section{DELAGO.}

Hybrid of Delaware pollinated by Goethe, produced in 1883 . Vine similar to Delaware, but more vigorous and a much heavier cropper. Cluster medium, shouldered, same shape as Delaware; berry large as Concord, ovate, beautiful red, about same shade as Delaware, very persistant; skin thin but tough, enabling the variety to endure shipment to any distance; pulp meaty, tender, of finest quality, possessing a delightful muscat flavor; seeds one to two, medium to large. Owing to the flower having short, recurved stamens, we have refrained from introducing this Grape until the present 


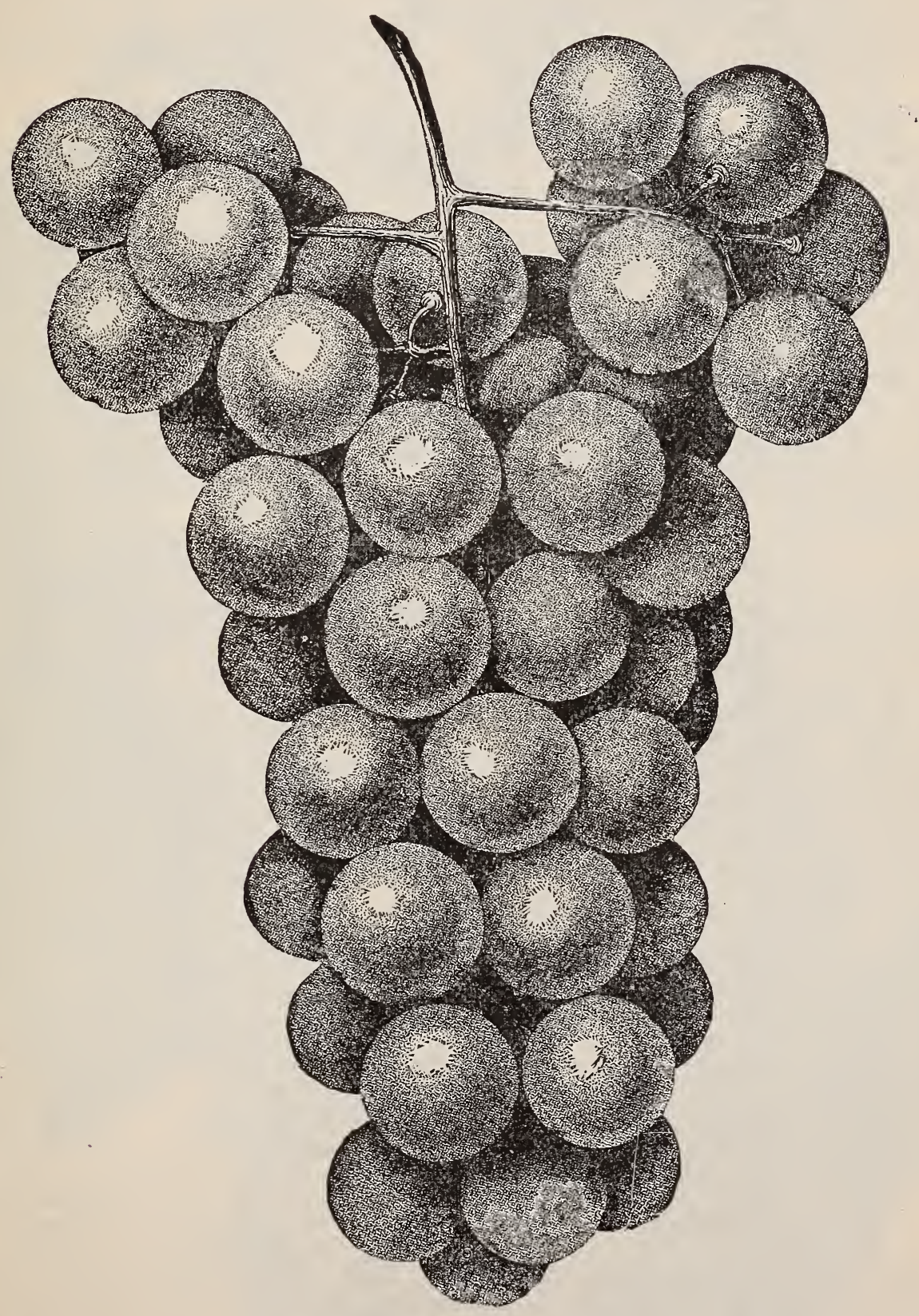

GOLD COIN GRAPE. (See page I4.) 
GRAPES, continued.

time, fearing it might not set its crop well but after thirteen years constant fruiting, in two different vineyards on some twenty vines, uniformly bearing good crops of such handsome and delicious Grapes, praised by every one who had seen and tasted it, we have concluded to offer vines of it for sale, at $\$$ I each.

\section{AMERICA.}

This is a seedling of Hermann Jaeger's No. 70, which is a hybrid becween the best selected Vitis Lincecumii and Vitis rupestris, native of Missouri, hence has pure American blood of two of our best species. The vine is very vigorous and productive, comes into and sheds its foliage very late; free from disease. It flowers late, and is perfect in fertilization. The vine is very hardy to resist heat and cold, and the roots to resist phylloxera. Clusters large berry medium to large, black, and rarely touched by rot; skin thin; pulp tender; juicy, pure and good; juice rich in coloring matter and sugar. Very promising as a dark-red wine as well as a good market Grape. Succeeds over a large extent of country. Will surely become a favorite among wine producers and marketmen. $25 \mathrm{cts}$. each, $\$ 2.50$ per doz.

\section{JAEGER.}

A hybrid produced in $\mathrm{I} \mathrm{S}_{5}$ by using pollen of the Herbemont upon one of the best varieties of I Itis Lincecumii found wild in this vicinity. Vine exceedingly vigorous, healthy and prolific. It will probably en dure the winters as far north as $40^{\circ}$. Bunch very large, shouldered or double-shouldered, compact; berry medium, of a dark purple, covered with a rich bloom; very persistent to the stem; skin thin, tough; pulp melting, very juicy, sweet and sprightly, of very good quality ; seeds small. A very attractive and valuable Grape for market, table or wine. Ripens with or a few days later than Concord. $25 \mathrm{cts}$. each, $\$ 2.50$ per doz.

\section{LONG JOHN.}

A hybrid of Big Post-Oak with Triumph. Vine vigorous, hardy; cluster very large, long, cylindrical ; berry large, black; skin thin and tough; seeds, two to four, medium ; pulp juicy and of good quality. A very attractive Grape in market on account of its large and fine appearing clusters. Ripens just with Concord, and a much better Grape every way. 5o cts. each, $\$ 5$ per doz.

\section{CARMAN.}

(See plate, page I8.)

A hybrid produced by using pollen of Triumph upon one of the best of our North Texas Post-Oak Grapes (Vitis Lincecumii). It leaves out and sheds late, and blooms late, always setting and maturing a very heavy crop, its vigor enduring this heavy crop from year to year with impunity. The vine appears as hardy as the Concord wherever tried, it having passed $27^{\circ}$ below zero in Missouri without damage. Its foliage and fruit so far have been almost entirely exempt from disease of every kind. Clusters very large, shouldered, conical; berry medium to large, black, very persistent; skin thin but tough ; pulp meaty and fairly juicy, with little coloring matter; flavor pure; rich, very sweet, of high quality; exceedingly promising. $25 \mathrm{cts}$. each, $\$ 2.50$ per doz.

\section{DELICIOUS.}

A hybrid of Big Post-Oak with Herbemont. Vine very vigorous and free from disease; cluster large, conical; berry medium, black; seeds small, one to three; skin thin and tough; pulp melting. The name of the Grape describes ts flavor. Productive; a fine table and wine Grape. 50 cts. eacl, $\$ 5$ per doz.

\section{BIG EXTRA.}

A hybrid of Post-Oak and Triumph. Vine vigorous and healthy, productive; cluster large, cylindrical; berry large, black; seeds medium, two to four ; skin thin, tough ; pulp tender and of very good quality. $50 \mathrm{cts}$. eacli, \$5 per doz.

\section{GOLD COIN.}

(See plate, page I3.)

Produced by pollinating Norton with Mar. tha in 1883 . Vine vigorous, late in leafing, shedding loaves and in flowering; flowers perfect; very hardy and productive; cluster medium, oval, or shouldered; berry medium to large; persistent, rich golden yellow when fully ripe; rarely touched by rot; skin thin, but very tough; pulp somewhat tough, very juicy, pleasant, agreeable flavor, becoming very sweet when fully ripe. Ripens about with Catawba; shows up and sells well in the market; immensely superior to the Pocklington. Will undoubtedly make an excellent white wine of good keeping quality. This Grape, wherever tested, has received very high praise. $25 \mathrm{cts}$. each, $\$ 2.50$ per doz.

\section{ELVICAND.}

The Black-Land Grape.

A hybrid of Elvira with the Texas Mustang Grape Vitis candicans, which grows and thrives so wonderfully everywhere in the black lands of the state. Vine exceedingly vigorous; medium to late in leafing out and flowering; flowers perfect. The vine has proved perfectly hardy in New York and Missouri, in the latter state having passed safely a temperature of 27 degrees below zero. Exceedingly productive of small to medium, compact clusters of medium to large, beautiful, translucent, dark-red berries, which are exceedingly persistent to the stems, and ripen a little later than Concord, and hold on until late in September in Texas, becoming better and better all the time-a most valuable point. Skin thin. tough; pulp tender, juicy, melting when fully ripe, and of a very refreshing honeyed sweetness, and of a peculiarly agreeable pure flavor; seeds, one to three, of medium size. In this Grape we have a combination 


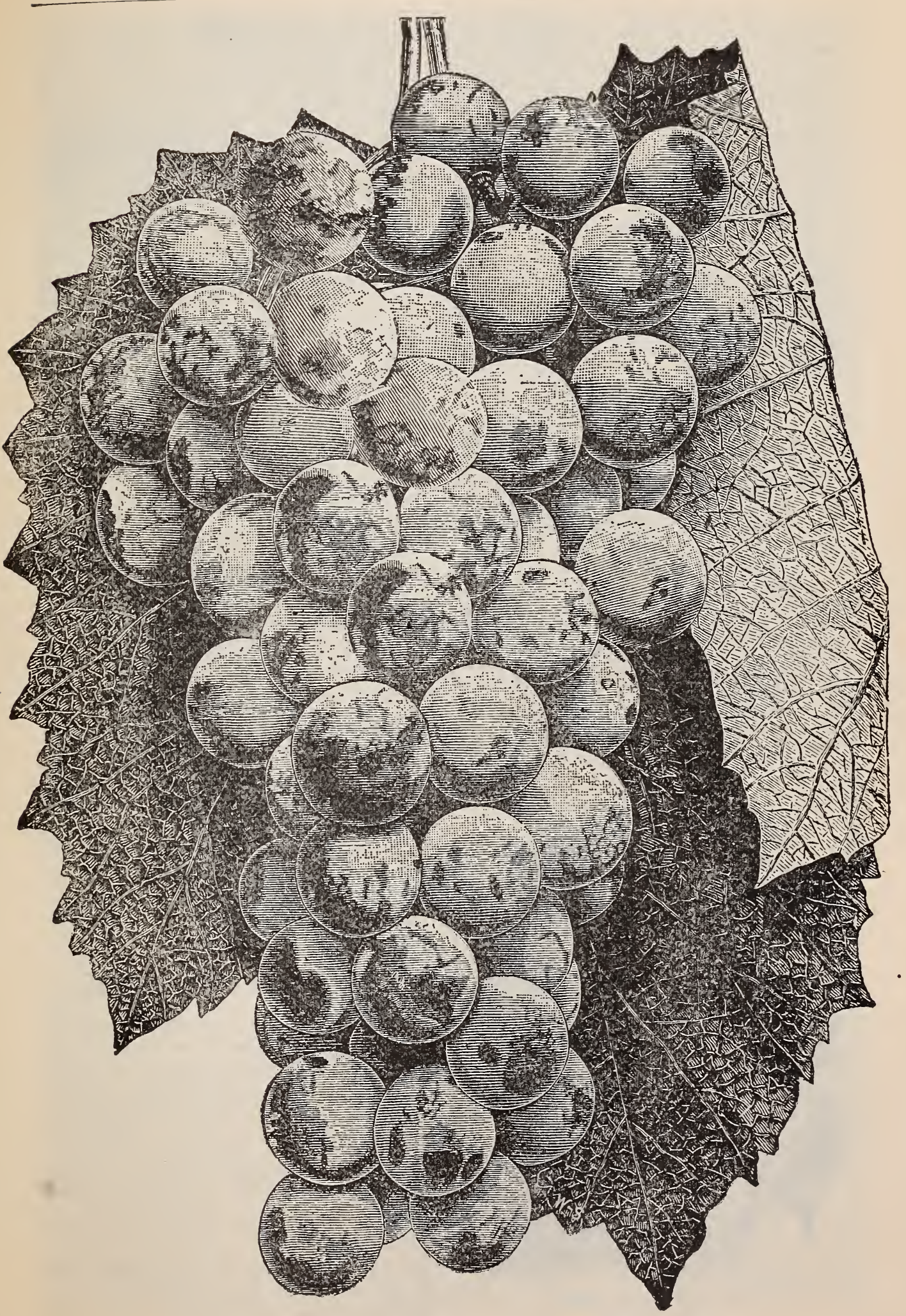

BRILLIANT GRAPE. (See page 12.) 
of three American species of Grapes, and it will compare favorably in appearance and quality of berry with some of the vinifera varieties, and is at once perfectly resistant to phylloxera on its own roots and little subject to fungous diseases. This variety is worthy of the most extended trial in the black lands of Texas, where so few Grapes do any good. This is the pioneer of a distinct and new family of Grapes. 50 cts. each, $\$ 5$ per doz.

\section{BIG HOPE.}

A hybrid of Post-Oak and Triumph. Vine vigorous, productive and free from disease ; cluster very large, cyíindrical and sometimes doubled; berry medium, dark red ; seeds small, two to three; skin thin and tough; pulp tender, with a pale red juice quality very good. $50 \mathrm{cts}$. each, $\$ 5$ per doz.

\section{MUENCH.}

A seedling of Neosho crossed with Herbe mont. Vine very vigorous, productive and healthy, free from all diseases; cluster large, fairly compact, conical; berry medium, dark purple; seeds small, one to three; skin thin and tough: pulp melting, and of best quality; white juice. $50 \mathrm{cts}$. each, $\$ 5$ per doz.

\section{MRS. MUNSON.}

Another Neosho cross with Herbemont. Vine thrifty, prolific and free from disease cluster, large, conical, shouldered; berry small to medium, purple; seeds one to three small ; skin thin and tough; pulp juicy and melting; quality of the best. A fine eating Grape as well as a valuable Grape for wine A fine variety for the South. Ripens two weeks later than the Herbemont. $50 \mathrm{cts}$. each, $\$ 5$ per doz.

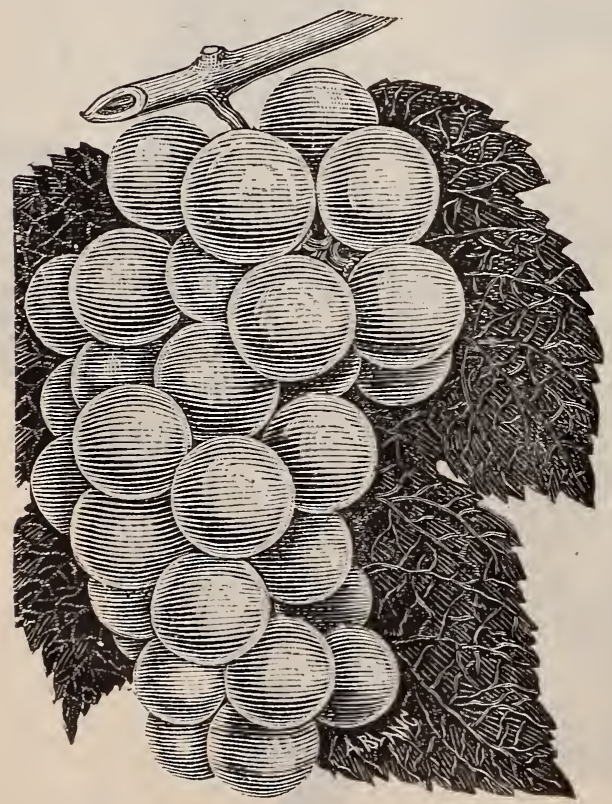

MOORE'S DIAMOND.

(See page ro.)

\section{HOPKINS.}

A hybrid of Post-Oak (Vitis Lincecumii) with Norton. Vine very vigorous. prolific: and an extra strong grower, free from any disease; cluster very large, cylindrical; berry medium, black; skin thin and tough; seeds two to three, small; pulp juicy and tender; of good quality. Makes wine of same character as Norton. 50c. each, $\$ 5$ per doz.

\section{FERN MUNSON.}

A hybrid of the Texas Post-Oak Grape (Vitis Lincecumii) and the Catawba. Vine very vigorous, late in leafing out, flowering and ripening of fruit; flowers perfect, cluster and berry large; berry persistent, very dark purple, almost black; skin thin, tough; pulp tender, juicy, rich and sprightly, of very fine quality. Ripe here in August, long after Concords are gone, and when the market is bare of other Grapes. Continues a long time, and is very valuable. Succeeds throughout the South, endures great drouth, and is little troubled by disease. $50 \mathrm{cts}$. each, $\$ 5$ per doz.

\section{LAUSSEL.}

A hybrid of Post-Oak with Gold Coin. Vine very vigorous and productive; ripens after the Fern and before the Marguerite; cluster medium to large, roundish; berry medium, dark purple; seeds small, two to four; skin thin and tough; pulp juicy and tender, of fine quality; pale red juice. A fine market and wine Grape, as well as for the table. $50 \mathrm{cts}$. each, $\$ 5$ per doz.

\section{MARGUERITE.}

A hybrid of Post-Oak with Herbemont. Prolific; the latest of all to ripen, and a fine Grape to succeed Laussel and Fern. Vine very vigorous and free from disease; cluster medium to above, often shouldered, cylindrical; berry medium, dark purple ; seeds one to three, small; skin thin and tough ; pulp juicy, melting and of best quality. A fine Grape for the South. 50 cts. each, $\$ 5$ per doz.

\section{A NEW ERA IN GRAPE CULTURE.}

We have hundreds of most favorable testimonials voluntarily written us by practical grape-growers, from all parts of the country, praising the above Grapes, each for its proper region, in unqualified terms. Thus by their own merits are they rapidly becoming popular. With the above list, with ordinary vineyard culture, one can in the South have a fine succession of choice fruit from June 25 (here at Denison $34^{\circ}$ north latitude) until in October. This truly marks a new era in Grape culture in the South. 


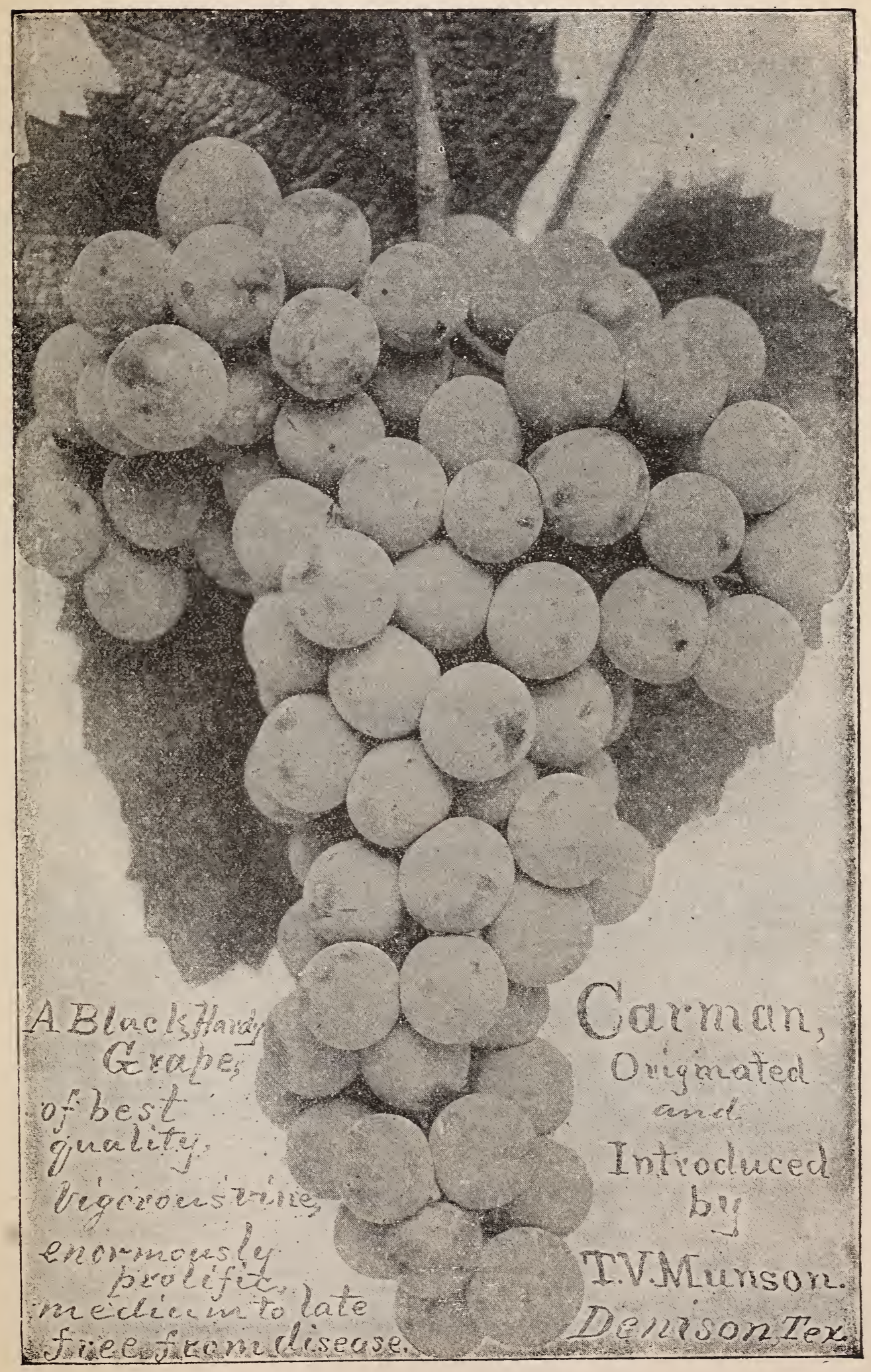




\section{JAPANESE PERSIMMON.}

This remarkable fruit does well all through the South. These are grown from seeds of several of the finest Japan varieties, that have all proved hardy and prolific here. Many that we have fruited of these seedlings have always been hardy, large, good and prolific, and give better satisfaction than grafted trees. We have never known a seedling Japan Persimmon to fail to bear. $40 \mathrm{cts}$. each, in many unnamed varieties.

\section{AMERICAN HONEY PERSIMMON.}

We have a tree of the native Persimmon found wild, bearing profusely of large, clear honey-colored fruit of. finest quality, preferred by all to even the finest Japanese kinds. The tree was moved into our grounds among the Japan varieties, and continues to fruit abundantly annually. It has few small seeds in comparison with most varieties. All things. considered, it is the finest Persimmon known to us. We annually grow some tr?es from seeds of this. About one-half of the seedling American Persimmons bear fruit, the others. are male; hence in filling orders we put in two trees for every one ordered. Io cts. each.

\section{NUT TREES.}

Two valuable varieties are offered, which will succeed in this country.

Select Texas Pecan. Large, nutmegshaped; thinnest shell, best quality. The Pecan is the finest nut known, and is destined soon to be cultivated extensively for commercial purposes. Our trees are grown from the nuts finest in size, in thinness of shell and excellence in quality we have ever tested, and were all gathered from isolated trees, hence will generally produce fine nuts; trees I to 3 feet transplant easily. I5 cts.. each, \$10 per I00, \$75 per I,000.

Juglans cordiformis. (Heart-shaped Japan Walnut) This is one of the finest nuts known, and is yet scarce, even in Japan, where it originated. The nut cracks easily, and the kernel drops out whole. The tree is hardy and very handsome, as well as very productive. 2-year-old trees, $50 \mathrm{cts}$. each.

\section{POMEGRANATE.}

Spanish Ruby. This is a fruiting variety, and probably the finest in cultivation. Fruit 2 to 3 inches in diameter, containing within the rind numerous sprightly juicy berries. Succeeds everywhere within 300 miles of the Gulf. 50 cts. each.

\section{ELAEAGNUS LONGIPES, GoUmi.}

Here is a magnificent shrub, with leaves dark green above and silvery beneath, perfectly hardy, bearing a crimson, cherry-like fruit (with one small, long seed), of refreshing, tart flavor, making an immense crop every year, and ripening in May here. Surely worth attention and planting considerably. $50 \mathrm{cts}$. each.

\section{HARDY ORANGE. (Citrus trifoliata.)}

A divarfish, handsome, thorny tree, blooming profusely and sweetly as any Orange, thus giving the rich, sweet "Orange Blossoms" far north, as it has proved hardy at ro to 20 degrees below zero. Makes a lovely specimen alone, with bright, small Oranges (not edible); one of the grandest of ornamental hedge plants, as well as for single specimens. Io cts. each, \$1 per doz., \$6 per Ico.

\section{"A TREE FULL OF ROSES."}

\section{Bechtel's Double Rose-colored Crab Apple.}

This is a true American Crab Apple, producing quantities of fine, very fragrant, full double flowers, closely resembling roses. It is one of the rarest, most truly meritorious novelties ever introduced. Its beauty and worth are recognized by the most noted and reliable horticulturists in the country, and those who plant it on our recommendation will be thankful for the hint. \$I each. 


\section{Shade and Ornamental Trees.}

4 to 5 feet, 15 cts.; 6 to 8 feet, 20 cts., 8 to $10 \mathrm{feet,} 25 \mathrm{cts}$, unless otherwise noted.

Your chief happiness lies in the growing ornaments surrounding your home. Such ornaments refine and purify. Neglect them not!

Black Locust ( Sweet Locust). A splendid dry-climate shade, ornamental or grove tree. Every prairie farm should have a grove of this for shade and fence posts. 6 to $8 \mathrm{ft}$., $20 \mathrm{cts}$.

Box Elder. Hardy, handsome, longlived, easily transplanted; a fine stock on hand.

Elaeagnus argentea. Silver berry ; very handsome, small, silver-leaved tree. $25 \mathrm{cts}$.

Lombardy Poplar. Quick, ornamental, easy to transplant.

Mulberry. Excellent, quick-growing, long-lived, easy to handle; non-fruiting.

MULBERRY, RUSSIAN IVEEPING. The most beautiful and successful weeping tree for a dry climate ever introduced; difficult to propagate, but easy to transplant. \$i each.

MAPLE, Soft or Silver. The best; a tavorite; quick, hanđsome, beautiful scarlet in fall. Have a fine stock. Can make low prices on large orders.
Japan Varnish Tree. A peculiar and striking tree, with straight, smooth, green body, and large-lobed leaves, in umbrellalike head. 50 cents each.

Prunus Pissardii. Foliage and fruit beautiful, permanent, bright purple. $20 \mathrm{cts}$. each.

SIVEET GUM (or Liquidambar). A most beautiful native shade tree for the South, leaves turning crimson and scarlet in fall.

SYCAMORE. Quick, hardy, long-lived, no disease. Have a fine stock.

VITUS AGNUS-CASTUS INCISA (Mint. Tree). A remarkable, perpetualflowering, small tree, hardy throughout the South, producing innumerable spikes of rich blue, highly scented, mint-like flowers, much liked by bees. The leaves are divided like a hand, into five to seven finger-like leaflets. $50 \mathrm{cts}$. each.

Weeping Willow. Succeeds well on deep, rich soil. $25 \mathrm{cts}$ each.

\section{FLOWERING SHRUBS.}

\section{All Tested, and Successful in Texas.}

Almond, Double-flowering. Pink, 25 cts. each; White, 25 cts. each.

Budleya Lindleyana. Very graceful, everblooming; profusion of purple spikes. 25 cts. each.

Bush Honeysuckle. Bloom in February; very fragrant. $25 \mathrm{cts}$. each.

CRAPE MYRTLE. Splendid summer bloomers. Crimson and Pink, I5 cts. each ; White, 25 cts. each.

Crape Myrtle, MUNSON. An improved, rich, imperial pink; 50 cts.

CALIFORNIA PRIVET. Splendid for speciments, screens or hedging, 2 to 3 feet. Io cts. each,; smaller, for hedging, 4 per roo. Have large stock.

Cephalanthus occidentalis (Button Bush). Handsome, sweet; ball-shaped heads of flowers, beautiful foliage. I5 cts.

Deutzia crenata. Splendid shrub; double pink. I5 cts. each.

Deutzia WVatsonii. Very double; pure white ; finest of all. I5 cts. each,

Flowering Willow (Chilopsis Saligna). A fine tree-like shrub, blooming profusely from spring on all through the summer; flowers purplish, I to 2 inches long, tubular. 25 cts. each.
Lilac. Large Purple, Persian, White, Prince Notger, De Marley and others; wellknown favorites. I5 cts. each.

Myrica cerifera. An evergreen near the Gulf. Compact, broad, glossy leaves. For massing it makes a very agreeable effect; perfectly hardy in all weather. 2 to $3 \mathrm{ft}$., $15 \mathrm{cts}$. each.

Pyrus Japonica (Scarlet Quince). A gorgeous sight in early spring. I5 cts. each.

Pomegranate. Double Scarlet and Salmon; half hardy, fine for tubs. $25 \mathrm{cts}$. each.

Spiræa Prunifolia and Reevsei. Both double white, blooming in succession. I5 cts.

Spiraea Billardii and Thunbergii. Both pink, perpetual. I5 cts. each.

Spiraea argentea and Fontaneysii. Both white, perpetual. I5 cts. each.

Tamarix plumosa. Novel, graceful, flowering in perpetual sweet pink spikes. $25 \mathrm{cts}$. each.

Weigela rosea. Bell-shaped, rose-collored; a favorite. $15 \mathrm{cts}$. each.

White Fringe. Beautiful broad, dark green leaves; snow-white, fringe-like, pendulous flowers, in spring; very beautiful 25 cts. each. 


\section{Ornamental Vines.}

'Ampelopsis quinquefolia (American Ivy). Fine to cover walls. I5 cts. each.

Ampelopsis Veitchii. Still more handsome than the American. $25 \mathrm{cts}$. each.

Cissus incisa. A most lovely, thick, waxy-leaved climber; it grows from tubers; hardy anywhere in the South. $25 \mathrm{cts}$. each.

\section{CLIMBING ROSES. Tennessee} Belle-blush; Crimson Rambler-deep crimson. 25 cts, each.

HONEYSUCKLES. Monthly Sweet -buff; profuse, perpetual bloomer. $25 \mathrm{cts}$. each. Scarlet Trumpet - nearly perpetual; handsome. 25 cts. each. Yellow Trumpet-a nice mate for the scarlet. 25 cts. each.

Trumpet Creeper. A stout, woody, handsome vine, with compound leaves and perpetual, waxy, large, tubular, orange flowers in clusters ; fine to ornament outhouses, tree bodies, etc., as it climbs by aerial roots. $25 \mathrm{cts}$. each.

Wistaria. American purple. $25 \mathrm{cts}$.

Vitis rubra. Hardy; rare, but exquisitely beautiful ; dark, glossy leaves; good climbing Grape for trellis or arbor. $25 \mathrm{cts}$. each.

Vitis monticola. Hardy, rare, very handsome; small light green, glossyleaves; clean grower. $25 \mathrm{cts}$. each.

Vitis Munsoniana. Most graceful, weeping, beautiful; glossy, lively green leaves; vigorous grower; for bowers, arbor or trellises; hardy only in Gulf states, but for growing inside North it is superb, Native of southern Florida. $25 \mathrm{cts}$. each.

\section{ROSES.}

Strong, open ground, 1 Jear, $25 \mathrm{cts}$, eacb, $\$ 2.50$ per doz., excert where noted.

The following list includes the most superb varieties, both old and new. The plants are thrifty, vigorous, growing in open ground, one year old. WVe have a large stock, and n quantity can make low prices.

All these have been in bloom throughout the season, and we know them to be strictly pure and true to name and description.

\section{Everblooming. WHITE AND BLUSH.}

Bride. Strong, healthy, large, double, fine bud; delicate carmine-blush.

Clothilde Soupert. Vigorous, profuse bloomer, with medium, very full, white flowers.

Marie Guillot. Moderate grower. creamy white; large, very full; none finer.

The Queen. Pure snow-white; sweet and fragrant; petals are thick, and makes fine buds on long stems; good grower.

Kaiserin Augusta Victoria. Pure white, fragrant; fine buds and flowers on long stems; profuse; strong grower.

Viscountess Folkestone. Strong, healthy; flower large, resembling the Pæony; delicately tinted flesh, almost pure white.

Souv. Madame Eugene Verdier. Profuse, large globular flowers; white, with delicate tints.

Augustine Guinoiseau (White La France). Habit of La France; strong; flower white, with delicate shades; large petals.

\section{BUFF AND YELLOW.}

Golden Gate. Vigorous, profuse ; large full flowers of excellent fragrance; buds long, and admirably formed; color creamy white, tinged with flesh.

Marie van Houtte. Free; flowers large and full; white, slightly tinged with yellow, edge of petals lined with rose.
Etoile de Lyon. Rich yellow, fragrant, pretty; profuse all summer, during hottest weather; good grower.

Climbing Perle. Flowers and buds similar to the Perle; as a climber, is much stronger, although similar to Marechal Niel in habit.

Dr. Grill. Coppery yellow, medium flower; petals narrow, almost quilled.

Mad. Welche. A fine, rich, fragrant cream, salmon center; medium grower.

\section{PINK.}

Catherine Mermet. Vigorous, large, full; bright flesh color; very sweet.

Duchesse de Brabant. Vigorous, freebloomer; salmon-pink; very sweet.

La France. Strong, upright, very large, full ; delicate pink, sweet, profuse.

Pink Soupert. Resembles the Clothilde Soupert in habit and style, only the flower is pink.

Bridesmaid. Sport of and similar to Catherine Mermet, except the color is of a clearer and deeper pink.

Reine Marie Henriette. Plant of a climbing habit; buds on long stems; flowers large and full; color a pure shade of cherryred.

Duchess of Albany. Habit of plant, shape and size of flower similar to that of La France, but more profuse and of deeper pink. 


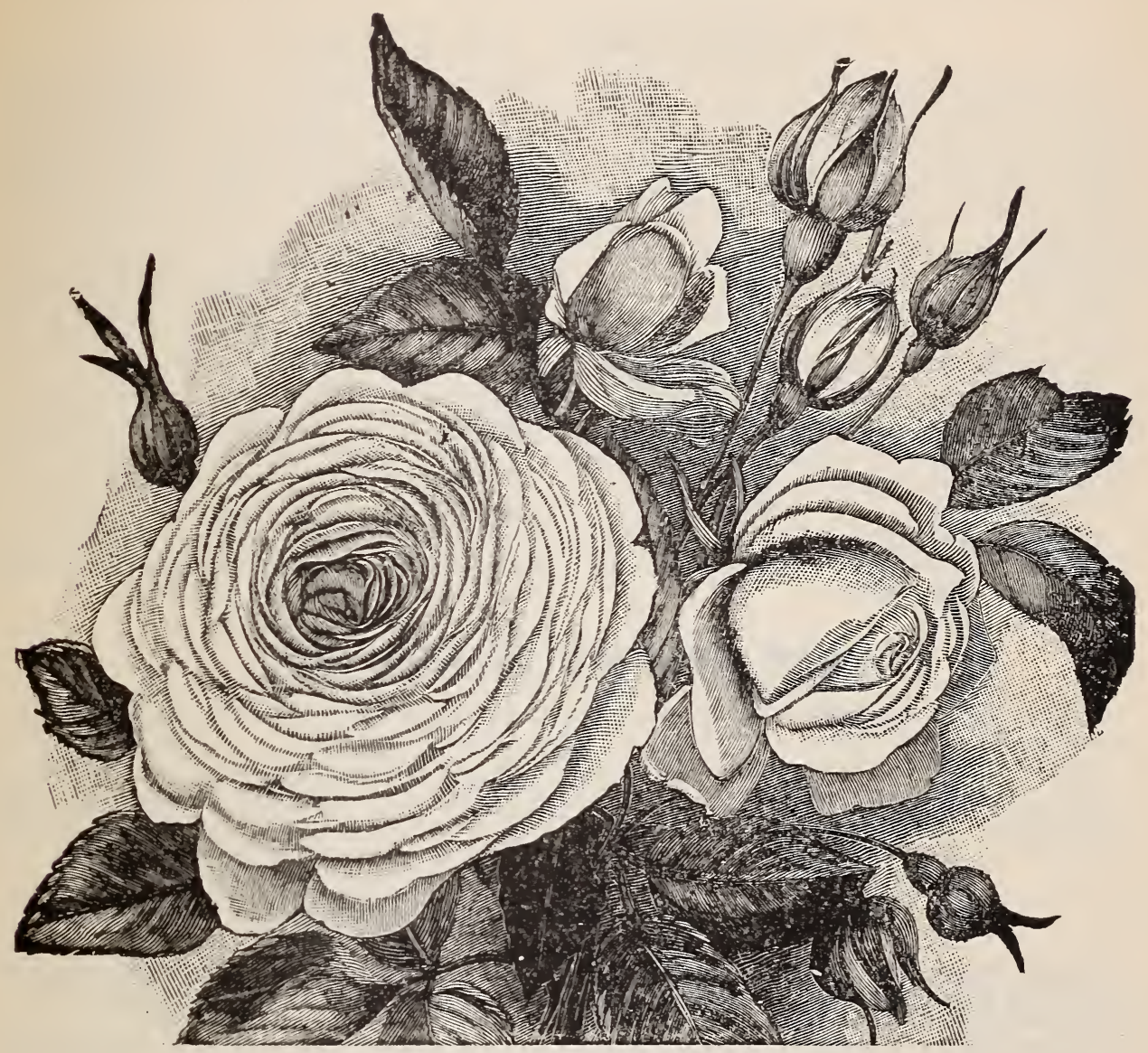

CLOTHILDE SOUPERT.

ROSES, continued.

Belle Siebrecht. Strong; large buds on long stems ; color imperial pink. $40 \mathrm{cts}$. each.

Mad. Lambard. Bronzy, profuse ; strong grower. fuse.

Hermosa. Clear, handsome pink; pro-

Mad. Cochet. Rose or pink, shaded with salmon; profuse, fine bud and flower; strong grower; a very superior Rose.

Mad. de Watteville. Rose color, outer tips of petals pencilled with a dark crimson on creamy yellow ground; free bloomer and a strong grower.

\section{SCARLET AND CRIMSON.}

American Beauty. Crimson, fine. 40 cts. each.

Wootton. Fine, rich crimson; good plant and flower.

Meteor. Large; clear, rich, dark crimson ; profuse ; strong grower.

Papa Gontier. Very handsome in bud; dark crimson.

Beauty of Stapleford. Full, fine, light crimson; fine in bud and flower; profuse, strong grower.
Princess Sagan. Profuse; medium, dark crimson; fine for bedding; makes a fine show.

Crimson Bedder. Very similar to Princess Sagan, only the flower is slightly smaller; very profuse, strong grower; an old standard bedder.

Pierre Guillot. Fine, full, persistent, crimson; strong grower; one of the best. We consider it superior to the American Beauty. $40 \mathrm{cts}$. each.

Madame Masson. Strong and hardy; flowers large and profuse, open and very double; flowers dark crimson.

Madame Chas. Wood. Similar to Mad. Masson, only plant is more stocky and color a little deeper crimson.

\section{Hardy Climbers.}

Tennessee Belle. Good climber; medium, full; blush; in clusters; profuse in spring.

Crimson Rambler. One of the finest climbers ; magnificent trusses of deep crimson flowers; makes a fine show as a climber and profuse bloomer. 


\section{PERENNIALS.}

Arundo Donax versicolor. A largegrowing perennial grass, with broad leaves beautifully ribboned with two shades of green and white. Also bears a plume late in fall, when in good growth. In clumps it makes a striking and pleasing effect. 25 cts. each.

Canna, Mad. Crozy. Large, scarlet-yellow border. I5 cts. each.

Canna, Chas. Henderson. Crimson. I5 cts. each.

Canna, Queen Charlotte. Yellow, with crimson spotted thwoat. All very large and fine. I5 cts. each.

Eulalia Japonica zebrina. Zebra Grass. The prettiest and most enduring of all grasses, producing plumes almost equal to Pampass Grass. I5 cts. each.

Eulalia gracillima univitata. Very vigorous, graceful, dark green "Fountain Grass." I5 cts. each.

\section{CONE-BEARING EVERGREENS.}

Arbor Vitæ, Chinese. Dark green; vigorous, hardy, desirable. I5 cts. per Pt.

Arbor Vita, Golden. Roundish, or conical, compact; beautiful. $20 \mathrm{cts}$. per ft.

Juniper, Trailing Tamarix-leaved. Very hardy; fine. $20 \mathrm{cts}$. per ft.

\section{BROAD-LEAVED EVERGREENS.}

Cape Jessamine (Gardenia florida). What the Magnolia is as a flowering evergreen tree, the Jassamine is as an evergreen flowering shrub. Flowers double, pearly white, wax-like petals, very sweetly scented. In regions north of the latitude of Waco, Texas, it needs winter protection; if put in tub in fall and kept as a stove plant, with good heat and light in house, will flower throughout the winter. $25 \mathrm{cts}$. each.

Evergreen Tree Box (Buxus semper. virens). A splendid, perfectly hardy, evergreen shrub; excellent for cemetery planting and for ornamental screens and hedging.
Juniper, Red Cedar. One of our best evergreens. I5 c. per ft., $2 \mathrm{ft} .25 \mathrm{C}$, $3 \mathrm{ft} .30 \mathrm{c}$.

Pinus Ponderosa. Rocky Mountain Yellow Pine. Very beautiful and successful; easy to transplant. I 2 to I 8 inches, 25 cts. each. $2 \mathrm{ft}$., $30 \mathrm{cts}$. each.

Have both the Myrtle-leaved and English. 6 in., Io cts. each ; I ft., I5 cts. each.

Magnolia grandiflora. This grandest of all evergreens and flowering trees succeeds throughout Texas and the Indian Territory, as well as in other Southern states. By clipping off all but a few of the tip leaves when taken up, and as treated in our handling, they are readily transplanted. I $\mathrm{ft}$. 25 c. each ; $2 \mathrm{ft}$., $50 \mathrm{c}$. each, 3 to $4 \mathrm{ft}$., 75 c. ea.

Mock Orange, or Wild Peach. A most beautiful broad-leaved, bright, glossy evergreen of great merit. 3 to $4 \mathrm{ft}$., $25 \mathrm{cts}$. each.

\section{JUICE OF THE VINE.}

For Table, Sacramental and Medicinal Use. Made from ripest choice Grapes.

Fresh Grape Juice ("Unfermented Wine"). This delicious beverage is one of the most appetizing, wholesome foods and remedial preparations known. It is equally efficient as fresh Grapes where the "Grape Cure" remedy may be recommended. All relish it; children cry for it. Most carefully prepared by a special process. In pint bottles, hermetically sealed, $30 \mathrm{cts}$. each, $\$ 3$ per doz. ; in quart bottles, hermetically sealed, $50 \mathrm{cts}$. $\bullet$ ach, $\$ 5$ per doz. Many churches use "Unfermented Wine" prepared by us.

\section{Addresses of Home Improvers.}

If you will send us with your order the names and post office addresses of six of your neighbors who own and are improving their homes, we will put in with your order, if as much as $\$ 2$ or over, articles from our list, of your own selection, to amount of 25 cents. For twelve such addresses, when order is $\$ z$ or more, articles to amount of 50 cents. This offer does not extend to more than twelve addresses from one customer. 


\section{T. V. Munson \& Son's Order Sheet.}

No. of Order

Filled by.
Date....

Packed by

(Please fill cut blanh below with yourorder, and mail with remittance perpostal order.)

, 189

T. T. MUNSON \& SON, DENISON, TEXAS:

For the amount remitted herewith, $\$$

as your sto nearly wase your judgment, in case you cannot fill exactly, by putting in what most nearly and satisfactorily will fill the place for the same money.

Slip by

to Station...

Care of.

P. $O$.

County

State

My residence is.

miles from the station. [If no substitution will do, so direct.]

Name

No. Street or Avenue.

\section{LIST OF ARTICLES.}

\begin{tabular}{l|l|l|l}
\hline No. & Name and Size of Article. & Dollars. & Cts. \\
\hline & & & \\
\hline
\end{tabular}


ORUER SHEET, continued.

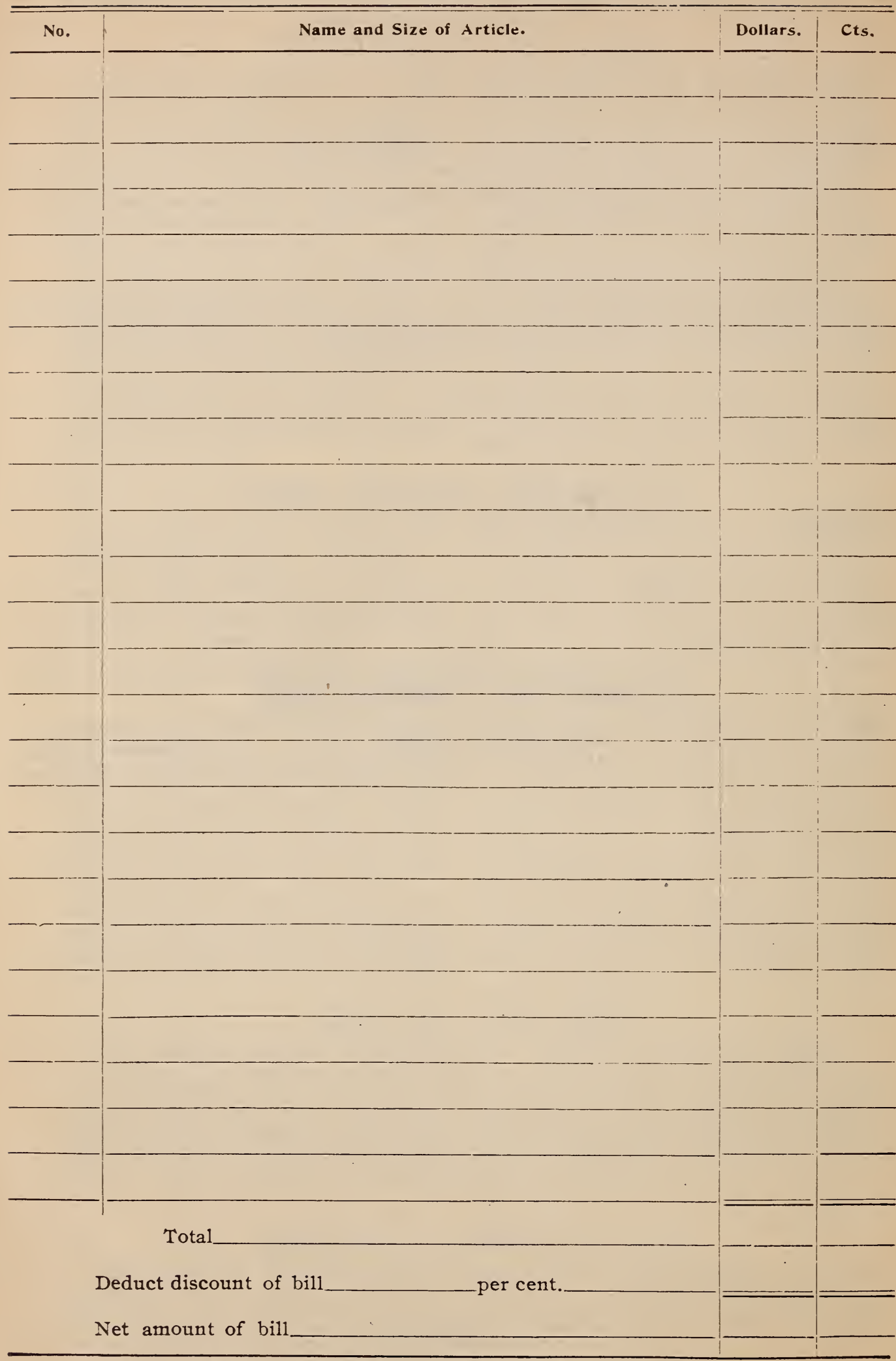

(If this sheet is not sufficient, continue same form on blank paper.) 


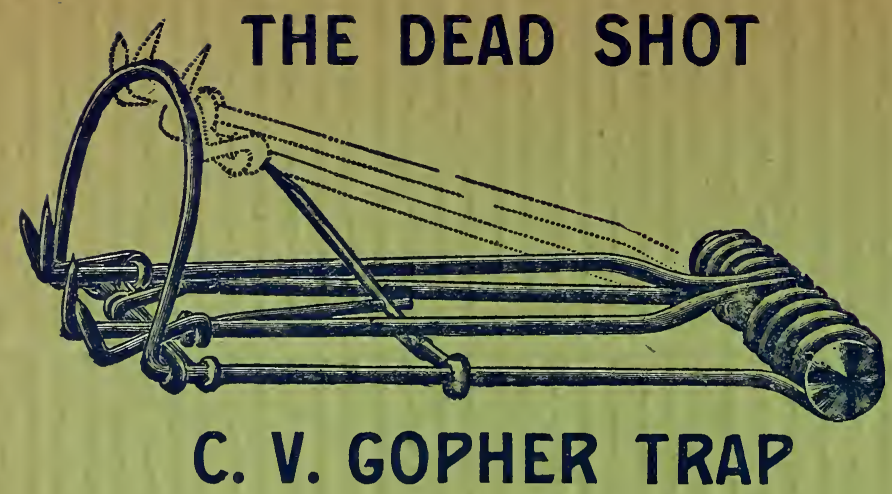

Just the thing you are looking for to destroy those destructive Pocket Gophers. Full directions for setting with each trap.

\section{5 cts. each, 3 for $\$ 1$, .. $\$ 4$ per dozen.}

We have used these traps for over ten years, and they have given entire satisfaction.

\section{NDEX}

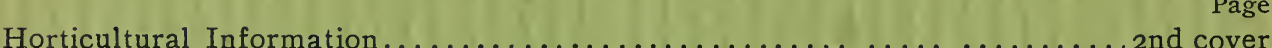

A Small Library of Most Useful Horticultural Books............... nd cover

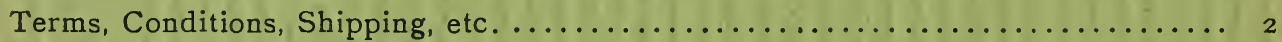

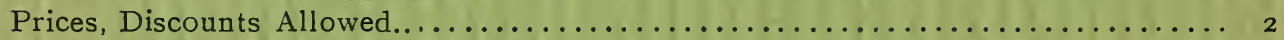

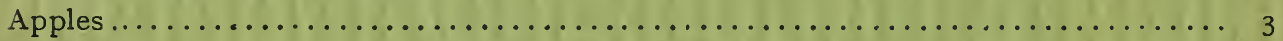

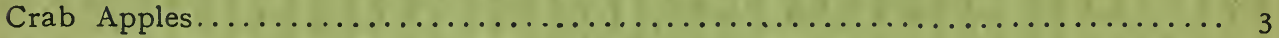

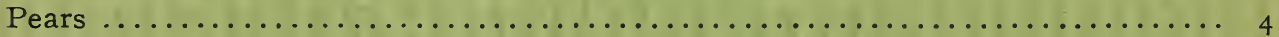

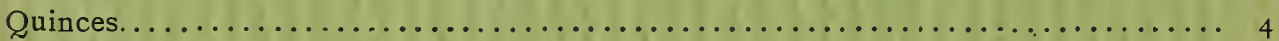

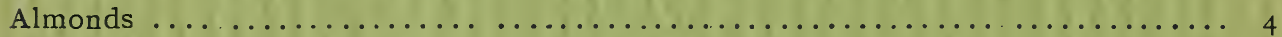

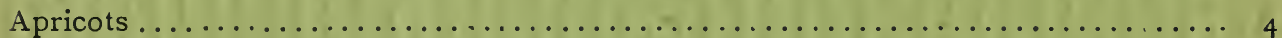

Cherries........................................... 4

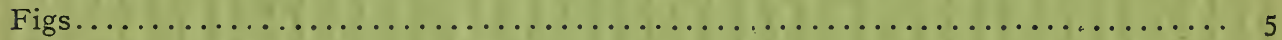

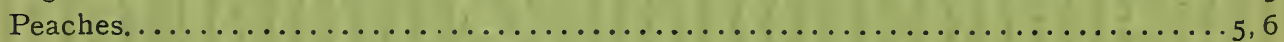

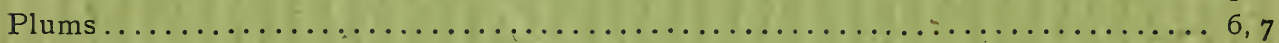

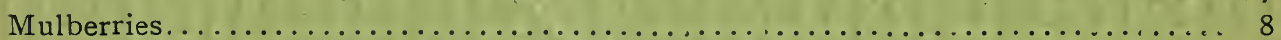

Blackberries . . . . . . . . . . . . . . . . . . . . . . . . . . . 8

Dewberries. .......................................... 8

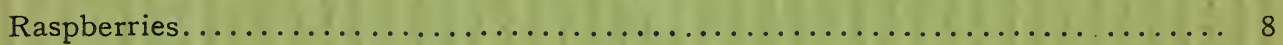

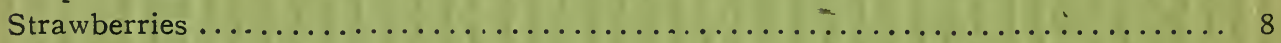

Grapes-Standard Varieties. ................................ I0

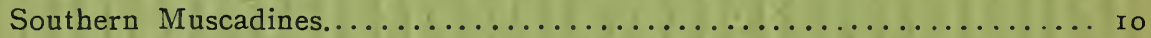

Vinifera Varieties.............................. I I

T. V. Munson's Hybrids and Seedlings.................. $\ldots \ldots \ldots \ldots \ldots \ldots \ldots$

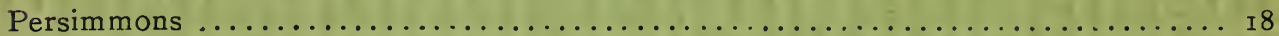

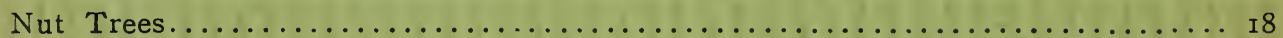

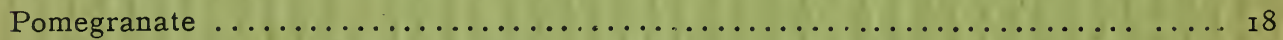

Elæagnus Longipes; Hardy Orange; "A Tree Full of Roses"............. I 8

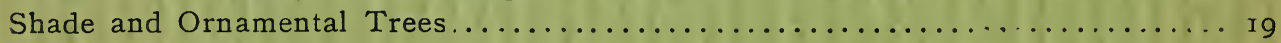

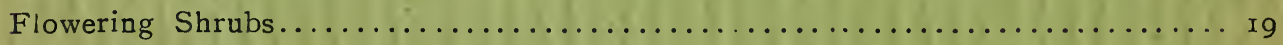

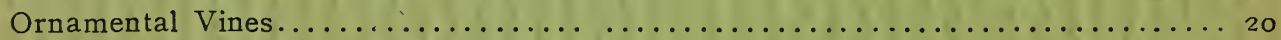

Roses............................................ 2 r

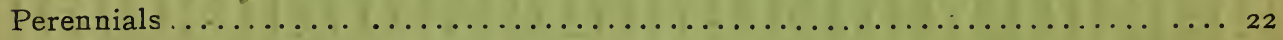

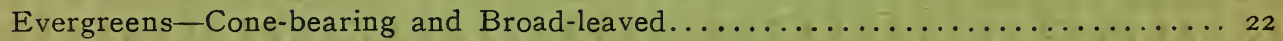

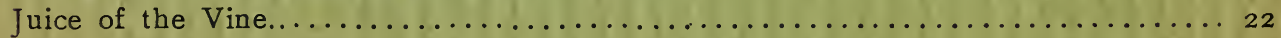

6714a J. Horace MicFarland Company, Horticultural Printers, Harrisburg, Pa. 